\title{
Aerosol properties, source identification, and cloud processing in orographic clouds measured by single particle mass spectrometry on a central European mountain site during HCCT-2010
}

\author{
A. Roth ${ }^{1}$, J. Schneider ${ }^{1}$, T. Klimach ${ }^{1}$, S. Mertes ${ }^{2}$, D. van Pinxteren ${ }^{2}$, H. Herrmann ${ }^{2}$, and S. Borrmann ${ }^{1,3}$ \\ ${ }^{1}$ Particle Chemistry Department, Max Planck Institute for Chemistry, Hahn-Meitner-Weg 1, 55128 Mainz, Germany \\ ${ }^{2}$ Leibniz Institute for Tropospheric Research, Permoserstraße 15, 04318 Leipzig, Germany \\ ${ }^{3}$ Institute for Atmospheric Physics, Johannes Gutenberg University Mainz, Johann-Joachim-Becherweg 21, \\ 55128 Mainz, Germany
}

Correspondence to: J. Schneider (johannes.schneider@mpic.de)

Received: 21 July 2015 - Published in Atmos. Chem. Phys. Discuss.: 8 September 2015

Revised: 17 December 2015 - Accepted: 19 December 2015 - Published: 19 January 2016

\begin{abstract}
Cloud residues and out-of-cloud aerosol particles with diameters between 150 and $900 \mathrm{~nm}$ were analysed by online single particle aerosol mass spectrometry during the 6-week study Hill Cap Cloud Thuringia (HCCT)-2010 in September-October 2010. The measurement location was the mountain Schmücke (937 m a.s.1.) in central Germany. More than 160000 bipolar mass spectra from out-of-cloud aerosol particles and more than 13000 bipolar mass spectra from cloud residual particles were obtained and were classified using a fuzzy $c$-means clustering algorithm. Analysis of the uncertainty of the sorting algorithm was conducted on a subset of the data by comparing the clustering output with particle-by-particle inspection and classification by the operator. This analysis yielded a false classification probability between 13 and $48 \%$. Additionally, particle types were identified by specific marker ions.

The results from the ambient aerosol analysis show that $63 \%$ of the analysed particles belong to clusters having a diurnal variation, suggesting that local or regional sources dominate the aerosol, especially for particles containing soot and biomass burning particles. In the cloud residues, the relative percentage of large soot-containing particles and particles containing amines was found to be increased compared to the out-of-cloud aerosol, while, in general, organic particles were less abundant in the cloud residues. In the case of amines, this can be explained by the high solubility of the amines, while the large soot-containing particles were found to be internally mixed with inorganics, which explains their
\end{abstract}

activation as cloud condensation nuclei. Furthermore, the results show that during cloud processing, both sulfate and nitrate are added to the residual particles, thereby changing the mixing state and increasing the fraction of particles with nitrate and/or sulfate. This is expected to lead to higher hygroscopicity after cloud evaporation, and therefore to an increase of the particles' ability to act as cloud condensation nuclei after their cloud passage.

\section{Introduction}

The interaction of aerosol particles and cloud droplets has several aspects: on the one hand, the presence of a cloud condensation nucleus (CCN) is an essential prerequisite for the formation of a cloud droplet, and the size and chemical composition of the aerosol particle determines whether a particle acts at a certain temperature and supersaturation as a $\mathrm{CCN}$ or not (e.g. Dusek et al., 2006b; Gunthe et al., 2009). On the other hand, cloud processing alters the chemical composition of the cloud droplet such that after evaporation of the cloud droplet the remaining aerosol particle is of a different composition than the original $\mathrm{CCN}$. The uptake of nitric acid in the aqueous phase of cloud droplets has been observed (Hayden et al., 2008), but also sulfate is known to be produced by oxidation of $\mathrm{SO}_{2}$ in the cloud phase, either by reaction with $\mathrm{O}_{3}$ (Bower et al., 1991), $\mathrm{H}_{2} \mathrm{O}_{2}$ (Bower et al., 1997; Laj et al., 1997a), or by transition metal induced oxidation (Harris 
et al., 2014). Both effects lead to a higher content of watersoluble inorganic material in the aerosol, which is expected to enhance the cloud formation potential of the particles.

Cloud particle sampling and separation from the not activated interstitial aerosol can be achieved by applying a counterflow virtual impactor (CVI; Ogren et al., 1985; Mertes et al., 2005b; Wendisch and Brenguier, 2013). This technique has been coupled with online aerosol mass spectrometry before, such that the composition of cloud droplets can be measured with high time resolution (Drewnick et al., 2007; Allan et al., 2008; Hayden et al., 2008). The use of single particle mass spectrometry for single cloud residual particle analysis (e.g. Gieray et al., 1997; Kamphus et al., 2010; Pratt et al., 2010; Zelenyuk et al., 2010) gives not only the composition of the bulk residues but also the mixing state of the cloud residues. Comparison with the aerosol observed shortly before cloud formation can give information on the possible addition of chemical compounds in the cloud phase and thereby evidence for cloud processing.

Several previous hill cap cloud experiments - considering the clouds as "stationary flow processors" - have been conducted and results have been reported in the literature. One of these is the FEBUKO experiment (Herrmann et al., 2005), which took place at the same field site as the Hill Cap Cloud Thuringia (HCCT)-2010 experiment reported here. The results from FEBUKO have shown a measurable increase of sulfate and ammonium, but only in two of three investigated cases, and only in the smallest particle size range (up to $140 \mathrm{~nm}$; Brüggemann et al., 2005). The mass production in the clouds was about $5 \%$ of upwind aerosol mass (in a size range between 60 and $300 \mathrm{~nm}$; Mertes et al., 2005a). Tilgner et al. (2005) found from model calculations for the same experiment that the mass increase is mainly due to $\mathrm{HNO}_{3}$ uptake and only to a lesser degree due to $\mathrm{SO}_{2}$ oxidation.

The Kleiner Feldberg Cloud Experiment (Fuzzi et al., 1994; Wobrock et al., 1994) was conducted in 1990. Offline single particle analyses of cloud residues sampled via a counterflow virtual impactor during this experiment are reported by Hallberg et al. (1994). It could be shown that the majority of cloud residues contained soluble compounds whereas insoluble particles remained in the interstitial air. Fuzzi et al. (1994) reported from the Feldberg Cloud Experiment that a general lack of gaseous $\mathrm{NH}_{3}$ was observed in the cloud systems. Thus, the clouds were acidic either by uptake of $\mathrm{HNO}_{3}$ or by oxidation of $\mathrm{NO}_{2}$ via $\mathrm{O}_{3}$ in the aqueous phase. $\mathrm{SO}_{2}$ oxidation in these clouds was inhibited by a lack of $\mathrm{H}_{2} \mathrm{O}_{2}$ and by the low $\mathrm{pH}$-values, such that the observed sulfate in the cloud water derived most likely from pre-existing aerosol.

During the Great Dun Fell experiment, which took place in 1993, an increased sulfate concentration of the aerosol was observed after cloud passing (Laj et al., 1997b). Thereby also the ammonium concentration increased based on the neutralisation reaction with ammonia. The increased sulfate concentration could be attributed mainly to $\mathrm{SO}_{2}$ oxidation by $\mathrm{H}_{2} \mathrm{O}_{2}$ in the cloud water and to a lesser extent by $\mathrm{O}_{3}$ (Bower et al.,
1997; Laj et al., 1997a). Furthermore, even though the concentrations of iron and copper were low, an influence of these elements on formation and depletion of photo-oxidants could be recognised (Sedlak et al., 1997).

Here we report the results obtained from individual particle chemical analysis by online single particle laser ablation mass spectrometry during the hill cloud experiment HCCT2010, which was conducted on the mountain site Schmücke in September and October 2010 in central Germany. The analysis includes cloud residual particles that were sampled from the cloud using a CVI and aerosol particles that were measured during cloud-free periods.

\section{Experiments and data evaluation procedures}

\subsection{Measurement site and instrumentation}

The HCCT 2010 experiment took place between 13 September and 25 October 2010, at the mountain ridge Thüringer Wald in central Germany. The same measurement sites were used as during two previous experiments (FEBUKO, 2001, 2002; Herrmann et al., 2005): (1) an upwind site (Goldlauter, $10^{\circ} 45^{\prime} 20^{\prime \prime} \mathrm{E}, 50^{\circ} 38^{\prime} 28^{\prime \prime} \mathrm{N}$; $605 \mathrm{~m}$ a.s.l.), (2) a summit site (Schmücke, $10^{\circ} 46^{\prime} 15^{\prime \prime} \mathrm{E}, 50^{\circ} 39^{\prime} 19^{\prime \prime} \mathrm{N}$; $937 \mathrm{~m}$ a.s.l.), and (3) a downwind site (Gehlberg, $10^{\circ} 47^{\prime} 32^{\prime \prime} \mathrm{E}, 50^{\circ} 40^{\prime} 21^{\prime \prime} \mathrm{N}$; $732 \mathrm{~m}$ a.s.l.). A map of the surroundings of the measurement site along with a table giving the population number of the cities within a radius of approximately $50 \mathrm{~km}$ around the site can be found in the Supplement (Fig. S1 and Table S1). At the summit site Schmücke, two particle inlets were installed facing south-west in separate windows at the height of $15 \mathrm{~m}$ of a three-story building that hosts a field station of the German Environmental Protection Agency (Umweltbundesamt). The aerosol inlet was used to sample aerosol particles with aerodynamic diameters $\left(d_{\text {aero }}\right)$ smaller than $5 \mu$ m under cloud free conditions. During cloudy periods the CVI (Mertes et al., 2005b) was additionally deployed to sample cloud droplets with diameters larger than $5 \mu \mathrm{m}$. The single particle aerosol mass spectrometer ALABAMA (Aircraft-based Laser Ablation Aerosol Mass Spectrometer) was operated while manually alternating between these two inlets. We did not attempt to detect interstitial aerosol because the ALABAMA size range (starting at $150 \mathrm{~nm}$; see below) does not permit detection of small, unactivated particles.

A detailed description of the mass spectrometer ALABAMA can be found in Brands et al. (2011). The particles enter the vacuum chamber via a Liu-type aerodynamic lens (Liu et al., 1995a, b) and are focused to a narrow particle beam. Due to the pressure drop the particles are accelerated when exiting the aerodynamic lens. The final particle velocity depends on their size, shape and density. The particles are detected by the scattered light of two orthogonal continuous wave $\mathrm{Nd}: \mathrm{VO}_{4}$ laser beams $(\lambda=532 \mathrm{~nm})$. The optical detection of the particles limits the particle size range for smaller 


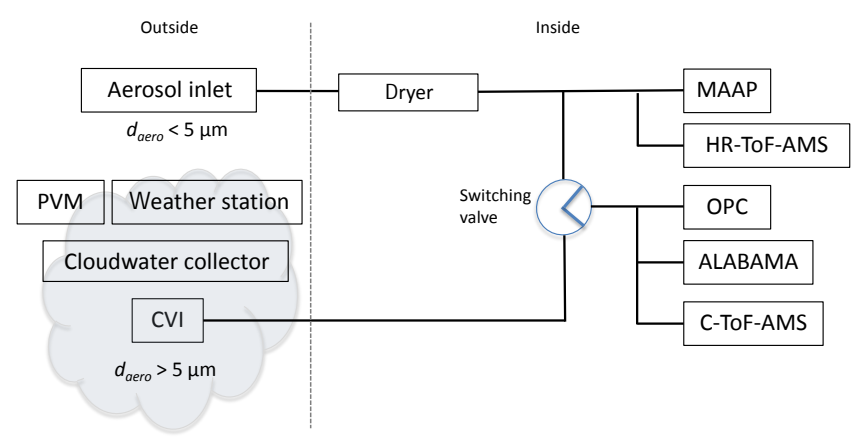

Figure 1. Measurement set-up and further operated instruments at the summit site Schmücke. Out-of-cloud aerosol was investigated by sampling through the aerosol inlet during cloud free periods while cloud residues were investigated by sampling through the CVI during cloud episodes.

particles to about $150-200 \mathrm{~nm}$. The particle size given as the vacuum aerodynamic diameter $\left(d_{\mathrm{va}}\right)$ can be derived from the time difference between the two scattering signals by means of calibration with particles of known size. In addition the time difference is used to calculate the time at which a particle will arrive at the ionisation region of the mass spectrometer. There the particle is evaporated and ionised in one step by laser ablation with a pulsed Nd:YAG laser $(\lambda=266 \mathrm{~nm})$. The resulting positive and negative ions are detected by a bipolar time-of-flight mass spectrometer. The laser ablation method is a qualitative method, such that it is not possible to relate the peak height to a mass concentration of a certain compound (e.g. Middlebrook et al., 2003).

Figure 1 shows the measurement set-up and additionally operated instruments at the summit site Schmücke. Besides the ALABAMA, an optical particle counter (OPC; Grimm, model 1.109, time resolution $6 \mathrm{~s}$ ) as well as a compact time-of-flight aerosol mass spectrometer (C-ToF-AMS; Aerodyne Research Inc., Drewnick et al., 2005) were run simultaneously. Furthermore a high-resolution time-of-flight AMS (HR-ToF-AMS; Aerodyne Research Inc., DeCarlo et al., 2006) and a multi-angle absorption photometer (MAAP; Thermo Scientific, model 5012, time resolution $1 \mathrm{~min}$ ) were operated continuously at the aerosol inlet. The MAAP determines the mass concentration of equivalent black carbon (EBC; Petzold et al., 2013) based on the absorption of particles sampled on a filter. The results from the C-ToF-AMS and HR-ToF-AMS measurements are presented in an accompanying paper (Schneider et al., 2016). Outside of the building, a particle volume monitor (PVM; Gerber Scientific Inc., model 100, time resolution $1 \mathrm{~min}$ ) for investigation of the liquid water content (LWC) and a weather station (Davis Vantage Pro) for meteorological parameters were installed. Additionally, Caltech active strand cloud water collectors (one stage, three stage, and five stage) were mounted. The $\mathrm{pH}$ value as well as the content of organic compounds of cloud water were analysed by offline methods at the Leibniz
Institute for Tropospheric Research. Furthermore, aliphatic amines were analysed from filtrated cloud water samples ( $0.45 \mu \mathrm{m}$ syringe filters, Acrodisc 13, Pall, Dreieich, Germany) using an ion chromatography method adopted from Facchini et al. (2008). Details of the method are given elsewhere (van Pinxteren et al., 2015).

\subsection{Definition of full cloud events (FCE)}

During the campaign, a measurement period was considered as a full cloud event (FCE) if the following criteria were fulfilled: LWC of the summit site cloud above $0.1 \mathrm{gm}^{-3}$, wind direction from the south-west (200-250 ${ }^{\circ}$ sector), wind speed at the Schmücke site between 2 and $12 \mathrm{~ms}^{-1}$, no fog at the two valley sites, no precipitation at any site, and air temperature above $0^{\circ} \mathrm{C}$. In the course of the data analysis, only those FCEs were chosen that fulfilled connected flow conditions, which were inferred using cross-correlations and coefficient of divergence (COD) for $\mathrm{O}_{3}$, particle number concentration in the Aitken mode $(49 \mathrm{~nm})$ and in the accumulation mode $(217 \mathrm{~nm})$. For details see Tilgner et al. (2014). Overall, 14 FCEs were identified and evaluated (Table 1). In this study we present the data from all cloud residue measurements behind the CVI, but the official FCEs are additionally analysed separately, thereby facilitating comparison with other data from HCCT-2010. FCEs showing insufficient number of mass spectra for statistical evaluations (FCE2.1, FCE4.1, FCE5.1, and FCE 26.2) are not considered in the following data analysis. Detailed information on cloud type and meteorological conditions of the individual FCEs can be found in the Supplement to Tilgner et al. (2014), a brief description of the cloud conditions is included in Table 1.

\subsection{Back trajectory calculation}

Back trajectories for the air masses encountered during HCCT-2010 were calculated using HYSPLIT (Hybrid Single Particle Lagrangian Integrated Trajectory; Draxler and Rolph, 2012). The air mass origin was determined $96 \mathrm{~h}$ before arriving at Mt. Schmücke with a time resolution of $1 \mathrm{~h}$. The coordinates of the Schmücke at a height of $500 \mathrm{~m}$ above the ground were used as an endpoint in the model. $500 \mathrm{~m}$ were chosen because the model orography cannot resolve a small-scale mountain range like the Thüringer Wald with sufficient detail. The back trajectories for the whole HCCT-2010 campaign can be found in the Supplement (Fig. S2). Back trajectories for the FCE are discussed in Sect. 3.3.

\subsection{Analysis of single particle mass spectra}

During the whole HCCT-2010 campaign the ALABAMA sampled over 286000 single particle mass spectra. The mass spectra were distinguished between out-of-cloud aerosol and cloud residual particles according to the inlets and the LWC. For the analysis of out-of-cloud aerosol only measurement periods with an $\mathrm{LWC}>0.05 \mathrm{~g} \mathrm{~m}^{-3}$ were considered $(402 \mathrm{~h})$, 
Table 1. Overview of the defined FCEs after Tilgner et al. (2014) during HCCT-2010 and the number of obtained single particle mass spectra by ALABAMA. FCE2.1, FCE4.1, FCE5.1, and FCE26.2 are statistically not significant.

\begin{tabular}{|c|c|c|c|c|c|}
\hline $\begin{array}{l}\text { Full cloud } \\
\text { event }\end{array}$ & $\begin{array}{l}\text { Start } \\
(\text { CEST) }\end{array}$ & $\begin{array}{l}\text { End } \\
(\text { CEST) }\end{array}$ & $\begin{array}{r}\text { Duration } \\
\mathrm{h}\end{array}$ & $\begin{array}{l}\text { Cloud } \\
\text { information }\end{array}$ & $\begin{array}{r}\text { Number of mass } \\
\text { spectra (cloud residues) }\end{array}$ \\
\hline FCE1.1 & 14-09-2010, 11:00 & 15-09-2010, 01:50 & 14.8 & $\begin{array}{l}\text { No pure orographic cloud, area covered by high clouds, } \\
\text { stable stratification }\end{array}$ & 1351 \\
\hline FCE1.2 & 15-09-2010, 03:00 & $15-09-2010,06: 20$ & 3.3 & Slight precipitation, slight stable thermal stratification & 128 \\
\hline FCE2.1 & $15-09-2010,23: 00$ & $16-09-2010,02: 00$ & 3 & $\begin{array}{l}\text { No pure orographic cloud, no precipitation, stable strat- } \\
\text { ification }\end{array}$ & - \\
\hline FCE4.1 & $16-09-2010,13: 10$ & $16-09-2010,15: 00$ & 1.8 & Slight precipitation, unstable thermal stratification & 5 \\
\hline FCE5.1 & $16-09-2010,21: 40$ & $16-09-2010,23: 50$ & 2.2 & No precipitation, slight stable stratification & 56 \\
\hline FCE7.1 & $24-09-2010,21: 10$ & $25-09-2010,00: 50$ & 3.7 & $\begin{array}{l}\text { Stable thermal stratification, orographic cloud, no pre- } \\
\text { cipitation }\end{array}$ & 238 \\
\hline FCE11.2 & $01-10-2010,20: 50$ & 02-10-2010, 03:10 & 6.3 & No precipitation, occlusion-related cloud & 117 \\
\hline FCE11.3 & 02-10-2010, 07:10 & 03-10-2010, 00:30 & 17.3 & $\begin{array}{l}\text { Slight precipitation at beginning of event, partly oro- } \\
\text { graphic cloud, higher clouds occurred, stable thermal } \\
\text { stratification }\end{array}$ & 974 \\
\hline FCE13.3 & $06-10-2010,06: 50$ & 07-10-2010, 01:00 & 18.2 & Rather stable thermal stratification, orographic cloud & 1131 \\
\hline FCE22.0 & $19-10-2010,01: 50$ & 19-10-2010, 09:00 & 7.2 & $\begin{array}{l}T<0^{\circ} \mathrm{C} \text {, rather stable thermal stratification, occlusion- } \\
\text { related cloud }\end{array}$ & 1561 \\
\hline FCE22.1 & $19-10-2010,21: 10$ & $20-10-2010,02: 30$ & 5.3 & $\begin{array}{l}\text { Slightly stable thermal stratification, lower stratiform } \\
\text { cloudiness }\end{array}$ & 248 \\
\hline FCE24.0 & 21-10-2010, 22:10 & $22-10-2010,10: 00$ & 11.8 & $\begin{array}{l}T<0^{\circ} \mathrm{C} \text {, quite stable thermal stratification, orographic } \\
\text { cloud pattern, slight precipitation }\end{array}$ & 588 \\
\hline FCE26.1 & $23-10-2010,23: 40$ & 24-10-2010, 07:20 & 7.7 & $\begin{array}{l}\text { less stable thermal stratification, no pure orographic } \\
\text { cloud, light precipitation }\end{array}$ & 356 \\
\hline FCE26.2 & $24-10-2010,08: 40$ & $24-10-2010,12: 20$ & 3.7 & Similar to FCE26.1, light postfrontal precipitation & 30 \\
\hline
\end{tabular}

while data sampled behind the CVI were only examined for an LWC $>0.1 \mathrm{~g} \mathrm{~m}^{-3}(228,106 \mathrm{~h}$ during FCEs). Upon inspection of the data set, a certain number of mass spectra were found to contain ions of only one polarity. The appearance of such monopolar mass spectra was also observed in other single particle mass spectrometer measurements (Bein et al., 2005; Sodeman et al., 2005; Shields et al., 2007; Pratt et al., 2010), resulting either from technical issues (e.g. tuning of high voltages) or from ion formation of only one polarity (Sodeman et al., 2005). Negative ion mass spectra provide better information on secondary organic and inorganic compounds (nitrate and sulfate) and thereby also on the mixing state of the particles. However, in order to constrain the analysis to a consistent data set, monopolar mass spectra were excluded and only mass spectra of both polarities were considered for the data analysis presented here. Out of the remaining 177752 bipolar single particle mass spectra 164595 were obtained while sampling out-of-cloud aerosol and 13157 while sampling cloud residues (out of these 4400 were obtained during FCEs).

\subsubsection{Clustering by fuzzy $c$-means algorithm}

The analysis method that is widely used and has become a standard method for single particle mass spectra data is the clustering of the data set by similarities of the mass spectra (e.g. Hinz et al., 1999, 2006; Silva and Prather, 2000; Murphy et al., 2003; Zelenyuk et al., 2006, 2008; Hinz and Spengler, 2007; Zhao et al., 2008; Dall'Osto et al., 2009). The analysis presented here was conducted using the software tool CRISP (version 1.127, 64 bit) that was recently developed at the Max Planck Institute for Chemistry (Klimach, 2012). It is based on the programming software IGOR Pro (version 6.3, WaveMetrics). CRISP facilitates processing and management of large data sets. Data processing includes mass calibration of the time-of-flight spectra, peak area integration, and either automated clustering by one of the implemented algorithms ( $k$-means or fuzzy $c$-means) or manual clustering by inspection of every mass spectrum. Furthermore, particle spectra can be selected by specified criteria or according to additional external data sets. Here the clustering was done using the fuzzy $c$-means algorithm (Bezdek, 1981; Bezdek et al., 1984; Hinz et al., 1999). The main reason for choosing the fuzzy $c$-means algorithm was that in a test with two distinct particle types from laboratory data the fuzzy $c$-means yielded the best results (Roth, 2014). Furthermore, the fuzzy $c$-means accounts for mass spectra that do not fit to any cluster by creating one additional group of spectra ("others"). These mass spectra can then be treated separately by searching for certain marker peaks (see Sects. 2.4.3 and 2.4.4). All 177752 bipolar mass spectra were first pre-processed separately by calculating the square root of the peak intensity for every peak in order to reduce peak intensity differences. Afterwards the mass spectra were normalised (positive and negative polarities separately) to the sum of the peak intensities. After concatenation of both polarities the entire mass spectrum was normalised again. In the algorithm the starting reference mass spectra for the clustering are chosen as fol- 
lows: the first mass spectrum of the data set is chosen as the first reference. Hereupon the distance between the first reference and all further mass spectra is calculated sequentially. If the Pearson correlation coefficient between the reference and the actual mass spectrum is smaller than a threshold (chosen here 0.8 ), the latter is regarded as being significantly different from the first reference spectrum and is added as a further start cluster reference. This procedure is repeated until the desired number of start clusters (here 200) is obtained. The membership coefficient $m_{i k}$ for every particle spectrum $i$ to a cluster reference $k$ is calculated by

$m_{i k}=\frac{1}{\sum_{j=1}^{c}\left(\frac{d_{i k}}{d_{i j}}\right)^{\frac{2}{f-1}}}$

with the number of clusters $c$, the "fuzzifier" $f$, and the distance $d_{i j}$ between mass spectrum $i$ and reference $j$. The sum of all membership coefficients equals 1 . The fuzzifier ( $1 \leq f \leq \infty$, originally introduced as "weighting exponent" by Bezdek, 1981) represents the fuzziness (blurring, defocusing) of the classification. The fuzzifier value of 1.7 applied here was chosen empirically on the basis of test data sets with known particle types and particle numbers. The distance $d_{i j}$ is calculated here based on the Pearson correlation coefficient $r_{i j}\left(0 \leq r_{i j} \leq 1\right)$ between the particle spectrum $i$ and the cluster reference $j$ via:

$d_{i j}=1-r_{i j}$.

Every mass spectrum is compared to the start clusters, calculating correlation coefficient, distance, and membership coefficient. Afterwards a mean mass spectrum of every cluster is calculated under consideration of the membership coefficients. The new mean cluster spectrum serves as reference for the following run. Again correlation, distance, and memberships are calculated for every mass spectrum to the new cluster references. This procedure is repeated until the membership difference of two consecutive iterations is smaller than a termination threshold (here: $10^{-4}$ ). Now every mass spectrum is assigned to that cluster for which the Pearson correlation coefficient $r_{i j}$ is the highest, but only if $r_{i j}$ is larger than a certain threshold (here 0.7). Mass spectra showing smaller correlation coefficients than this threshold are sorted out and assigned to an additional cluster ("others").

The clustering of the current data set resulted in 159 clusters. This number is smaller than the starting value of 200 clusters, confirming that the chosen number of 200 starting cluster was large enough and that no particle types that significantly differ from the others were missed by the algorithm. About $9 \%$ of all mass spectra were sorted out being represented by the fraction "others". According to the fragmentation pattern considering characteristic peaks for certain particle types, their combination (e.g. Hinz et al., 1999; Trimborn et al., 2002; Vogt et al., 2003; Dall'Osto and Harrison, 2006; Pratt and Prather, 2010; Corbin et al., 2012), and relative peak intensities, every cluster was assigned manually to a certain particle type. Afterwards the number of obtained clusters was reduced by combining clusters of the same particle type, if two mean cluster spectra $j$ and $k$ showed a Pearson correlation coefficient $r_{j k}$ larger than 0.7. In this way 65 cluster types remained, which were further grouped into 19 different fragmentation types (plus "others") representing 11 distinguished particle types (plus "others"), according to the criteria given in Table $3(\mathrm{~A}-\mathrm{K})$. All cluster mean mass spectra as well as further details on the separation of different clusters are shown in the Supplement (Figs. S3-S6; Table S2). Further particle types were determined by searching for specific marker peaks; see Sect. 2.4.3.

\subsubsection{Uncertainties of clustering by the fuzzy $c$-means algorithm}

By manual inspection of the cluster algorithm results, it was found that occasionally mass spectra were classified falsely by the algorithm, depending on cluster number and particle type. To take into account uncertainties of the resulting particle type fractions, the uncertainties were estimated by means of a reduced, representative data set of the HCCT2010 campaign. For this, 1377 single particle mass spectra were clustered by fuzzy $c$-means using the same parameters as described above. The resulting clusters were assigned to particle types based on their averaged mass spectrum. Afterwards the individual mass spectra of every particle type were reviewed manually. For example, 274 particle spectra were sorted into the particle type "org, K". The number of mass spectra being assigned falsely to the considered particle type was determined ( $\left.\Delta_{\text {false positive }}\right)$. In the case of "org, K", 51 mass spectra of this particle type belonged to a different particle type. The number of mass spectra being classified falsely to another particle type was also determined $\left(\Delta_{\text {false negative }}\right)$. In order to do this, all other clusters were inspected and the number of mass spectra belonging to "org, K" was counted. In this example, 43 mass spectra of the particle type "org, K" were assigned to clusters of other particle types by the algorithm. Since both false classifications are not dependent on each other, we chose to apply Gaussian error propagation for the determined uncertainty of a particle type $\left(\Delta_{\text {particle type }}\right)$ :

$\Delta_{\text {particle type }}=\sqrt{\Delta_{\text {false postitve }}^{2}+\Delta_{\text {false negative }}^{2}}$.

In the case of "org, K", $\Delta_{\text {particle type }}=67$, meaning that the error is about $24 \%$ of the absolute number of mass spectra of this cluster. This reduced test set contained no particles of the type "mineral dust" and "Ca". The uncertainty for the particle type "Ca" was therefore estimated by averaging the uncertainties of the other particles types, while the particle type "mineral dust" was further refined by the marker method and the uncertainty was inferred as explained in Sect. 2.4.3. Table 2 shows the details of the test data set along with the resulting uncertainties for the different particle types. In this test case, a total of $16 \%$ of all mass spectra 
were assigned to a wrong particle type. In relation to the absolute number of each particle type, $\Delta_{\text {particle type }}$ ranges between 13 and $50 \%$. The largest uncertainties are found for the particle types "diesel exhaust" $(50 \%)$, "amines" (35\%), "soot and org" (31\%), and "K" (30\%). The large error bar of the fraction "others" can be explained by the exclusion of mass spectra that would have been assigned manually to an existing particle type. The determined uncertainties were adopted for the clustering of the total data set.

\subsubsection{Particle type identification by marker peaks}

In addition to the clustering method that compares the whole mass spectra of the individual particles, it is also useful to search for certain marker peaks, especially in cases when these peaks are of small intensity such that they do not influence the correlation of two mass spectra and therefore do not show up in the clustering results. A typical example would be looking for metals (e.g. lead) or rarely appearing particle types (Dall'Osto et al., 2004; Tolocka et al., 2004; Snyder et al., 2009). By the marker method it was possible to identify two different particle types characterised by the abundance of iron, namely "mineral dust" and "Fe, V" (iron internally mixed with vanadium). Besides $\mathrm{Fe}^{+}$other indicators for mineral dust are $\mathrm{Na}^{+}(m / z 23)$ and $\mathrm{K}^{+}(m / z 39)$ (Silva et al., 2000; Hinz et al., 2006; Dall'Osto et al., 2010), whereas vanadium $\left(\mathrm{V}^{+}, m / z 51\right)$ originates from fuel combustion (Tolocka et al., 2004; Korn et al., 2007; Ault et al., 2010) and industrial sources like refineries (Dall'Osto et al., 2004; Ault et al., 2009) than from mineral dust. Details on the classification of iron-containing particles can be found in the supplementary material (Sect. 4, Fig. S7).

The method is also suitable for investigating the particle mixing state when looking at the abundance of, e.g. nitrate and sulfate independent of the particle type. Uncertainties for particle types derived by the marker method were estimated using counting statistics (square root of absolute number of counted particles).

\subsubsection{Combined analysis using clustering and marker peaks}

In order to optimise the data analysis and as a consequence of the two preceding sections, we chose to apply a combined method of clustering and marker peaks: after the clustering, the fraction "others" has been additionally investigated by marker peaks of lead, nickel, vanadium, and iron. Also the particle type characterised by iron inferred from the clustering method was analysed further using the marker peak method, resulting in two particle types: one interpreted as mineral dust and the other consisting of iron internally mixed with vanadium ("Fe, V"), belonging probably to an industrial source. Using the combined method of clustering and marker peak analysis, a total of 14 particle types plus "others" were identified. A summary of the resulting particle types, the ap- plied method and their characteristic signals for identification as well as the corresponding chemical composition in the mass spectra are listed in Table 3. Due to the fact that all particle types were internally mixed with secondary inorganic compounds like nitrate and sulfate, these compounds are not explicitly mentioned in the legend. The mean positive and negative mass spectra of the 14 particle types plus the averaged remaining mass spectra ("others") are shown in Fig. 2. An overview of all cluster types obtained by the clustering method can be found in the Supplement (Figs. S3-S6).

\section{Results}

\subsection{Size-resolved aerosol composition and identification of local sources}

Figure 3 shows the size-resolved particle composition for all particles (not separated for out-of-cloud aerosol and cloud residues). The relative fraction of all particles in the specific size class is given in order to eliminate the size-dependent detection efficiency of the ALABAMA (Brands et al., 2011). The total number of analysed particles per size bin is given by the grey line. The maximum of the analysed particles lies in the size range between 500 and $550 \mathrm{~nm}$, due to the best detection and ablation efficiency of the ALABAMA in this size range. The particle types shown in Fig. 3 refer only to the results obtained by the fuzzy $c$-means clustering; thus, the particle types "Fe, $\mathrm{V}$ ", "Ni", and "Pb" are contained in the type "others". The most abundant particle types are "org, K", "biomass burning", and "soot" (see also Table 4). The particle types "diesel exhaust" as well as "soot, org" only appear significantly at small vacuum aerodynamic diameters between 200 and $450 \mathrm{~nm}$. This indicates that these particles were recently emitted and had no time grow by condensation or coagulation. In contrast, the particle types "org", "amines", and "soot" are observed only with diameters larger than $450 \mathrm{~nm}$. This agrees with the observation that all analysed soot particles were internally mixed with nitrate and sulfate (see Sect. 3.4) and indicates that these soot particles were aged and have been processed and coated. Particles of the type "biomass burning" and "org, K" are found in all size classes, although the type "org, K" has a clear maximum between 400 and $500 \mathrm{~nm}$.

Figure 4 shows the number of detected particles as a function of the local wind direction at the Schmücke. Panel a gives the standard wind rose for the whole time period. The dominating wind direction was south-west, with about $50 \%$ probability for wind directions between 200 and $270^{\circ}$. This direction corresponds to the requirements for cloud events. The absolute number of detected particles is given in panel $\mathrm{b}$, showing that the majority of the detected particles were measured when the wind came from south-west. However, as shown in panel c, per unit of time more particles were detected when the local wind direction was between 0 and $90^{\circ}$. 
Table 2. Overview of particle types and the corresponding determined uncertainties of the clustering by the fuzzy $c$-means algorithm. The particle types "mineral dust" and "Ca" were not included in the reduced test data set.

\begin{tabular}{lrrrrr}
\hline Particle type & Number MS & $\Delta_{\text {false positive }}$ & $\Delta_{\text {false negative }}$ & $\Delta_{\text {particle type }}$ & $\Delta_{\text {particle type }}(\%)$ \\
\hline Org, K & 274 & 51 & 43 & 67 & 24 \\
Org & 162 & 21 & 1 & 21 & 13 \\
Amines & 162 & 14 & 54 & 56 & 35 \\
Soot & 125 & 4 & 19 & 19 & 15 \\
Soot and org & 120 & 12 & 35 & 37 & 31 \\
Diesel exhaust & 18 & 8 & 3 & 9 & 50 \\
Biomass burning & 223 & 14 & 36 & 39 & 17 \\
K & 106 & 31 & 8 & 32 & 30 \\
Sea salt & 23 & 3 & 5 & 6 & 26 \\
Others & 164 & 68 & 22 & 72 & 44 \\
\hline
\end{tabular}

Table 3. Overview of identified particle types and the characteristic peaks used for the assignment of clusters to a particle type. Additionally the observed chemical composition of the particle types and the denotation used in the following (legend) are listed. Secondary inorganic compounds like nitrate and sulfate were present in every particle type and have therefore not been used as characteristic signals for the separation of particle types.

\begin{tabular}{|c|c|c|c|c|}
\hline Category & Legend & Method & Characteristic signals & Corresponding chemical composition \\
\hline A & org, $\mathrm{K}$ & clustering & $\begin{array}{l}m / z 27\left(\mathrm{C}_{2} \mathrm{H}_{3}^{+}\right), 39\left(\mathrm{~K}^{+}\right), 43\left(\mathrm{C}_{3} \mathrm{H}_{5}^{+} / \mathrm{CH}_{3} \mathrm{CO}^{+}\right), \\
51\left(\mathrm{C}_{4} \mathrm{H}_{3}^{+}\right), 63\left(\mathrm{C}_{5} \mathrm{H}_{3}^{+}\right), 77\left(\mathrm{C}_{6} \mathrm{H}_{5}^{+}\right) ; \\
m / z-59\left(\mathrm{C}_{3} \mathrm{H}_{7} \mathrm{O}^{-} / \mathrm{C}_{2} \mathrm{H}_{3} \mathrm{O}_{2}^{-}\right) \\
-73\left(\mathrm{C}_{4} \mathrm{H}_{9} \mathrm{O}^{-} / \mathrm{C}_{3} \mathrm{H}_{5} \mathrm{O}_{2}^{-}\right) \\
m / z 12\left(\mathrm{C}^{+}\right), 18\left(\mathrm{NH}_{4}^{+}\right), 27\left(\mathrm{C}_{2} \mathrm{H}_{3}^{+}\right), \\
36\left(\mathrm{C}_{3}^{+}\right), 39\left(\mathrm{~K}^{+}\right), 43\left(\mathrm{C}_{3} \mathrm{H}_{5}^{+} / \mathrm{CH}_{3} \mathrm{CO}^{+}\right), 48\left(\mathrm{C}_{4}^{+}\right)\end{array}$ & organics, potassium, nitrate, sulfate \\
\hline B & org & clustering & $\begin{array}{l}m / z 27\left(\mathrm{C}_{2} \mathrm{H}_{3}^{+}\right), 43\left(\mathrm{C}_{3} \mathrm{H}_{5}^{+} / \mathrm{CH}_{3} \mathrm{CO}^{+}\right) \\
\mathrm{C}_{1-5}^{+}\end{array}$ & organics, nitrate, sulfate \\
\hline $\mathrm{C}$ & amines & clustering & $m / z 18\left(\mathrm{NH}_{4}^{+}\right), 59\left(\mathrm{~N}\left(\mathrm{CH}_{3}\right)_{3}^{+}\right)$ & amines, organics, nitrate, sulfate \\
\hline $\mathrm{D}$ & soot & clustering & $\mathrm{C}_{n}^{+} ; \mathrm{C}_{n}^{-}$ & soot, nitrate, sulfate \\
\hline $\mathrm{E}$ & soot and org & clustering & $\begin{array}{l}m / z 18\left(\mathrm{NH}_{4}^{+}\right), 27\left(\mathrm{C}_{2} \mathrm{H}_{3}^{+}\right) 43\left(\mathrm{C}_{3} \mathrm{H}_{5}^{+} / \mathrm{CH}_{3} \mathrm{CO}^{+}\right), \mathrm{C}_{n}^{+} \text {; } \\
\mathrm{C}_{n}^{-}\end{array}$ & soot, organics, nitrate, sulfate \\
\hline $\mathrm{F}$ & diesel exhaust & clustering & $m / z 23\left(\mathrm{Na}^{+}\right), 40\left(\mathrm{Ca}^{+}\right), \mathrm{C}_{n}^{+} ; \mathrm{C}_{n}^{-}$ & soot, sodium, calcium, nitrate \\
\hline G & biomass burning & clustering & $\begin{array}{l}m / z 39\left(\mathrm{~K}^{+}\right), \mathrm{C}_{n}^{+} ; \mathrm{C}_{n}^{-} \\
m / z 23\left(\mathrm{Na}^{+}\right), \quad 39\left(\mathrm{~K}^{+}\right), 43 \quad\left(\mathrm{C}_{3} \mathrm{H}_{5}^{+} / \mathrm{CH}_{3} \mathrm{CO}^{+}\right), \\
51\left(\mathrm{C}_{4} \mathrm{H}_{3}^{+}\right), \mathrm{C}_{n}^{+} ; \mathrm{C}_{n}^{-} \\
m / z 39\left(\mathrm{~K}^{+}\right) ; m / z-26\left(\mathrm{CN}^{-}\right)\end{array}$ & biomass burning, nitrate, sulfate \\
\hline $\mathrm{H}$ & $\mathrm{K}$ & clustering & $\begin{array}{l}m / z 39\left(\mathrm{~K}^{+}\right) ; m / z-46\left(\mathrm{NO}_{2}^{-}\right),-62\left(\mathrm{NO}_{3}^{-}\right) \\
-97\left(\mathrm{HSO}_{4}^{-}\right)\end{array}$ & potassium, nitrate, sulfate \\
\hline I & sea salt & clustering & $\begin{array}{l}m / z 23\left(\mathrm{Na}^{+}\right), 39\left(\mathrm{~K}^{+}\right) ; m / z-46\left(\mathrm{NO}_{2}^{-}\right),-62\left(\mathrm{NO}_{3}^{-}\right), \\
-97\left(\mathrm{HSO}_{4}^{-}\right)\end{array}$ & sodium, potassium, nitrate, sulfate (aged sea salt) \\
\hline $\mathrm{J}$ & $\mathrm{Ca}$ & clustering & $m / z 40\left(\mathrm{Ca}^{+}\right), 57\left(\mathrm{CaOH}^{+}\right)$ & calcium, soot, nitrate, sulfate \\
\hline $\mathrm{K}$ & mineral dust & clustering \& marker peak & $m / z 56\left(\mathrm{Fe}^{+}\right)$ & iron, sodium, potassium, calcium, nitrate, sulfate, phosphate \\
\hline $\mathrm{L}$ & $\mathrm{Fe}, \mathrm{V}$ & marker peak & $m / z 56, m / z 51, m / z 67$ & vanadium, iron, nitrate, sulfate \\
\hline $\mathrm{N}$ & $\mathrm{Ni}$ & marker peak & $m / z 58$ & nickel, iron, vanadium, nitrate, sulfate \\
\hline M & $\mathrm{Pb}$ & marker peak & $m / z 208$ & lead, sodium, nitrate, sulfate \\
\hline $\mathrm{O}$ & others & & & \\
\hline
\end{tabular}

In these directions lie several larger cities (Erfurt, Weimar, Jena; see map in Fig. S1) such that in general a higher pollution level may be expected.

Several particle types show a distinct diurnal pattern, indicating a source with a specific emission pattern. The fact that the emission pattern is detectable at the measurement site suggests that the source is not too far away, such that the diurnal pattern is not smoothed by different air mass transport velocities and different wind directions. An example is shown in Fig. 5. The figure shows the complete time series for the particle type "diesel exhaust" (upper panel) and the averaged diurnal pattern (lower panel). The diurnal pattern shows 

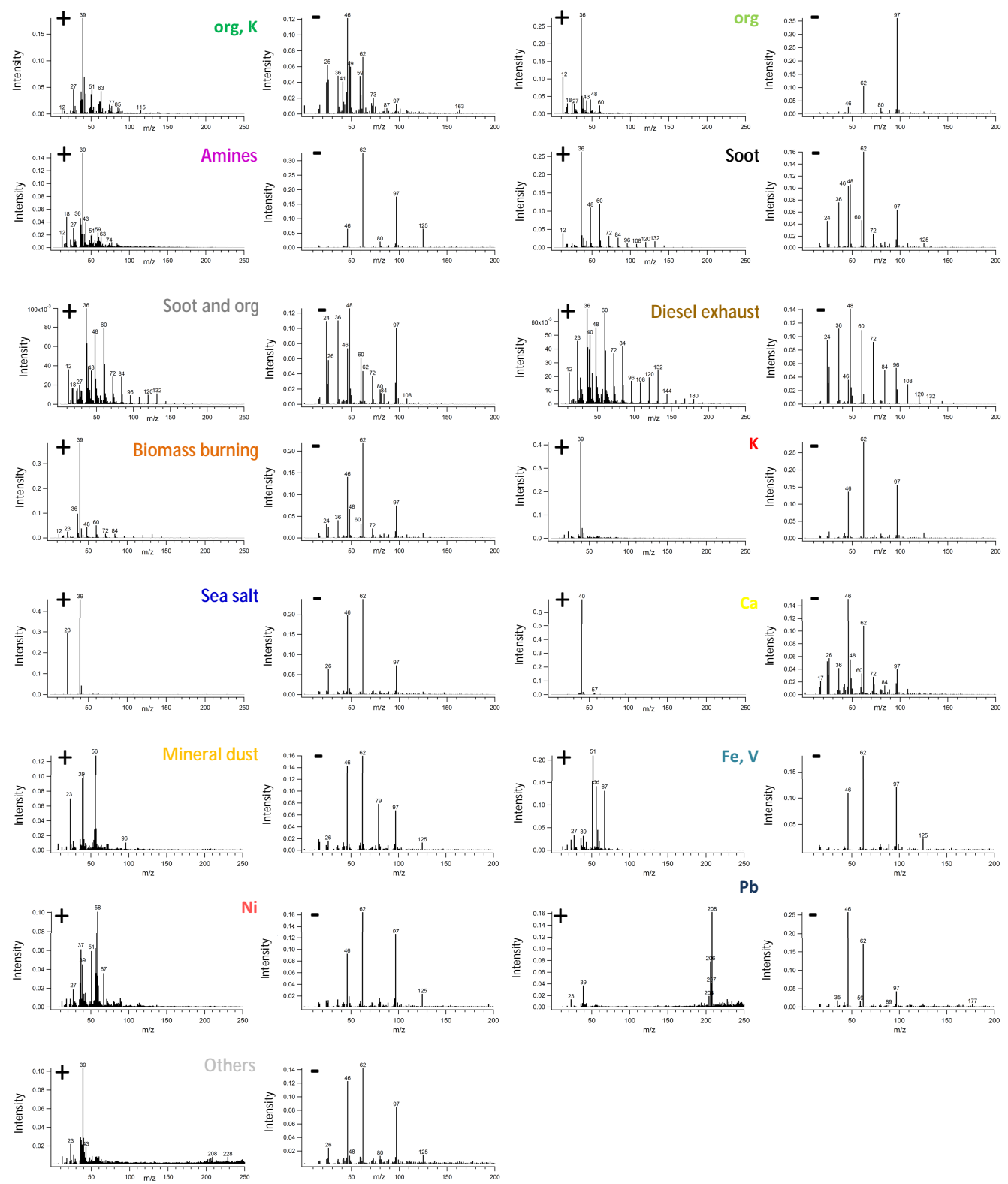

Figure 2. Mean positive (left) and negative (right) mass spectra representative of the particle types "org, K", "org", "amines", "soot", "soot and org", "diesel exhaust", "biomass burning", "K", "sea salt", "Ca", "mineral dust", "Fe,V", "Ni", "Pb" (with the separation of the Pb isotopes clearly visible), and "others".

the increased occurrence of particles of this type between 09:00 and 24:00 LT and a decrease of this particle type during the night. This indicates the contribution of traffic emissions from within 1 or 2 hours from the measurement site (local traffic typically starts around 07:00 in the morning). All clusters contained in each particle type were inspected for such a diurnal trend. From this the amount of particle influences by local or regional sources were obtained. Table 4 shows the relative abundance of the particle types during HCCT-2010 along with the percentage of clusters showing diurnal variations and those not showing a diurnal trend. In total, about $63 \%$ of the analysed particles belong to clusters indicating a diurnal variation. This finding implies that the aerosol composition during HCCT-2010 is mainly influenced by local and regional sources.

\subsection{Comparison of out-of-cloud aerosol and cloud residues}

One of the main objectives of this study was the analysis of cloud residues and the comparison to the aerosol composition under cloud-free conditions. Figure 6 shows the average 


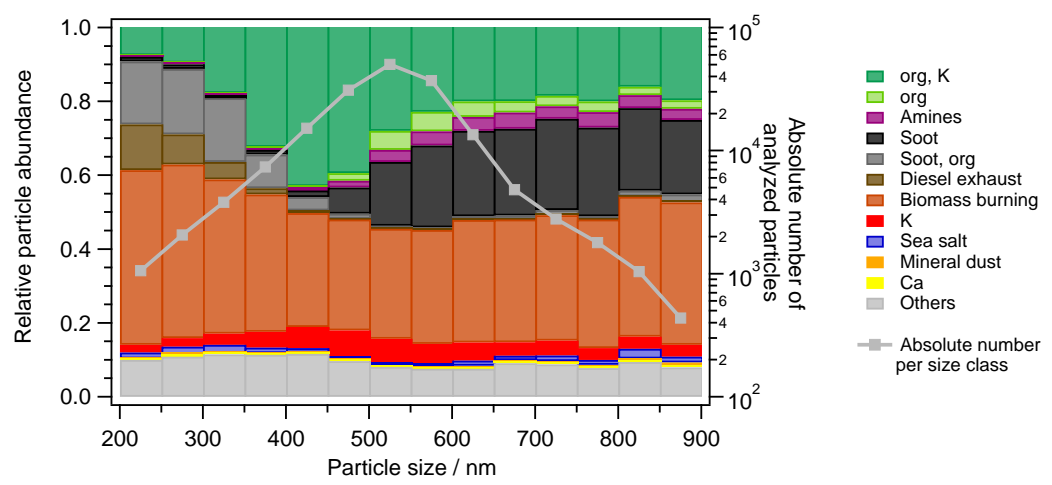

Figure 3. Size-resolved aerosol composition of the resulting particle types detected by the ALABAMA, binned into 50 nm size intervals. The absolute number of analysed particles per size class is given by the grey line.

Table 4. Absolute and relative particle numbers detected by ALABAMA during the HCCT-2010 campaign. The percentage of each particle type is subdivided into the fraction revealing a diurnal trend and into the fraction without diurnal trend. All percentages refer to the total number of 177752 analysed particles.

\begin{tabular}{|c|c|c|c|c|c|c|}
\hline $\begin{array}{l}\text { Particle } \\
\text { type }\end{array}$ & $\begin{array}{r}\text { Total } \\
\text { number }\end{array}$ & Percentage & $\begin{array}{l}\text { Number in clusters } \\
\text { with diurnal trend }\end{array}$ & $\begin{array}{r}\text { Percentage with } \\
\text { diurnal trend }\end{array}$ & $\begin{array}{l}\text { Number in clusters } \\
\text { w/o diurnal trend }\end{array}$ & $\begin{array}{r}\text { Percentage w/o } \\
\text { diurnal trend }\end{array}$ \\
\hline Org, K & 57163 & 32.2 & 27344 & 15.4 & 0 & 16.8 \\
\hline Org & 6295 & 3.54 & 6290 & 3.54 & 0 & 0.00281 \\
\hline Amines & 4910 & 2.76 & 4910 & 2.76 & 0 & 0 \\
\hline Soot & 25981 & 14.6 & 23546 & 13.2 & 0 & 1.37 \\
\hline Soot, org & 3931 & 2.21 & 2878 & 1.62 & 0 & 0.592 \\
\hline Diesel exhaust & 994 & 0.559 & 994 & 0.559 & 0 & 0 \\
\hline Biomass burning & 49873 & 28.1 & 37505 & 21.1 & 0 & 6.96 \\
\hline $\mathrm{K}$ & 10052 & 5.66 & 9035 & 5.08 & 0 & 0.572 \\
\hline Sea salt & 1927 & 1.08 & 0 & 0 & 1927 & 1.08 \\
\hline Others & 13967 & 7.86 & 0 & 0 & 13967 & 7.86 \\
\hline $\mathrm{Ca}$ & 263 & 0.148 & 0 & 0 & 263 & 0.148 \\
\hline Mineral dust & 756 & 0.425 & 0 & 0 & 756 & 0.425 \\
\hline $\mathrm{Fe}, \mathrm{V}$ & 569 & 0.242 & 0 & 0 & 569 & 0.32 \\
\hline $\mathrm{Ni}$ & 641 & 0.361 & 0 & 0 & 641 & 0.361 \\
\hline $\mathrm{Pb}$ & 430 & 0.242 & 0 & 0 & 430 & 0.242 \\
\hline Total & 177752 & 100 & 112502 & 63.3 & 65250 & 36.7 \\
\hline
\end{tabular}

aerosol particle composition for all out-of-cloud aerosol particles and all cloud residues measured during HCCT-2010, not restricted to the full cloud events. It has to be noted that measurements of cloud residues and out-of-cloud aerosol can by definition not be made simultaneously, such that differences in the meteorological condition influences such a comparison. In the following we will compare the relative abundance of the individual particle types between cloud residues and out-of-cloud aerosol.

\subsubsection{Organic particle types}

For both organic particle types ("org, K" and "org") the relative abundance in cloud residues is smaller than in the outof-cloud aerosol. This observation may partly be in contradiction with previous measurements reported in the litera- ture. For example, measurements of cloud residue composition by Drewnick et al. (2007) using an Aerodyne AMS reported increased organic mass fractions in cloud residues. However, these measurements are hard to compare because AMS data are based on average aerosol mass while the ALABAMA data are based on single particle analysis. Furthermore, Drewnick et al. (2007) did not consider refractory species in the aerosol composition and did not separate the organic mass into different subgroups. For example, in our study the particle types "soot" and "biomass burning" reveal a significant fraction of the aerosol composition (see below), and aerosol originating from biomass burning can be a significant fraction of the "organic" aerosol mass reported by the AMS (e.g. Lanz et al., 2010; Crippa et al., 2013, 2014). The AMS data from the HCCT-2010 campaign that are presented in a companion paper (Schneider et al., 2016) show 

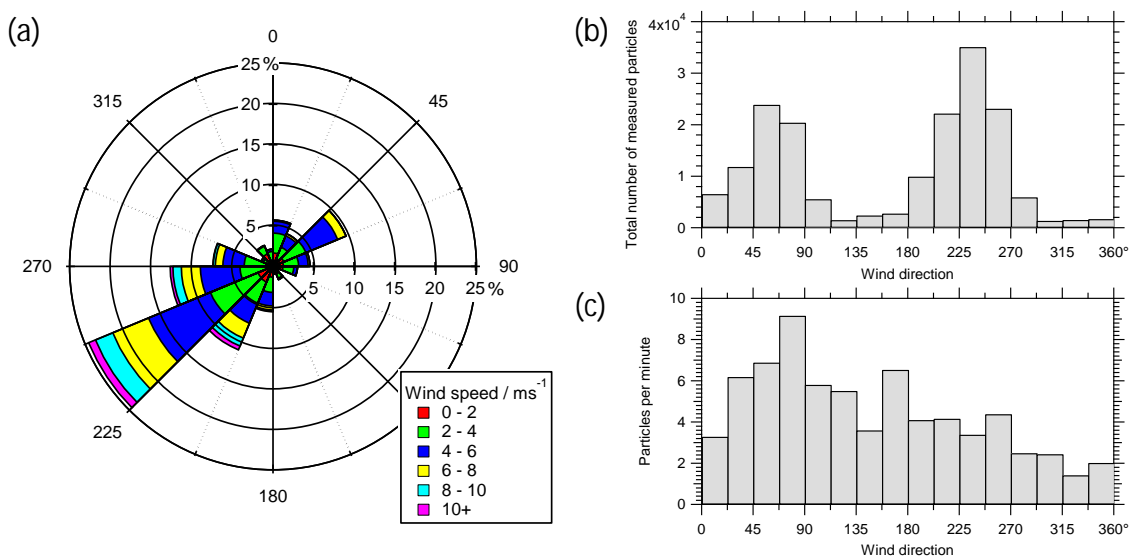

Figure 4. (a) Wind rose showing wind speed and direction for the whole time period. (b) Absolute number of analysed particles per wind direction. (c) Same as (b) but normalised to the measurement time per wind direction.

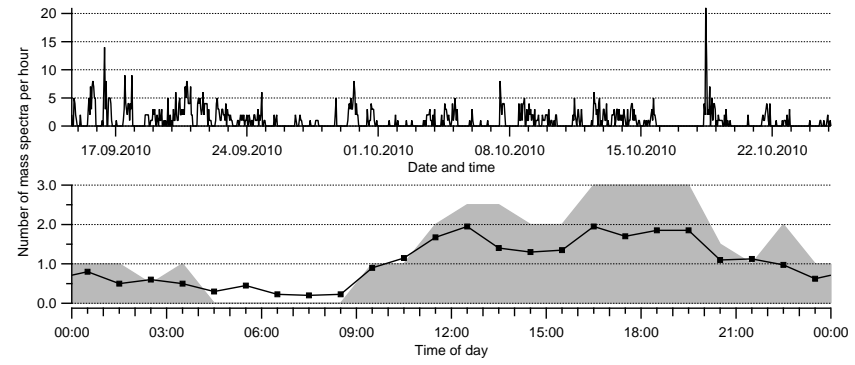

Figure 5. Time series (top) and diurnal variations (bottom, LT) of the particle type "diesel exhaust" during HCCT-2010. Markers denote the mean values, the grey shaded area represents the upper quartile.

a slightly lower scavenging efficiency for organics than for nitrate and sulfate. In-cloud scavenging of organic particles depends on the solubility of the organic compounds (Limbeck and Puxbaum, 2000). The slightly lower scavenging efficiency may therefore be explained by the lower solubility of hydrophobic organic compounds like aromatics, whose fragments were frequently observed in our single particle mass spectra $\left(\mathrm{C}_{4} \mathrm{H}_{3}^{+}(m / z 51), \mathrm{C}_{6} \mathrm{H}_{5}^{+}(m / z, 77), \mathrm{C}_{9} \mathrm{H}_{7}^{+}(m / z, 115)\right.$; see mass spectrum "org, K_2" in Fig. S3).

\subsubsection{Amine-containing particles}

Several characteristic peaks for amines have been reported in the literature, the most common appear to be $m / z 59$ $\left(\left(\mathrm{CH}_{3}\right)_{3} \mathrm{~N}^{+}\right)$and $m / z 74\left(\left(\mathrm{C}_{2} \mathrm{H}_{5}\right)_{2} \mathrm{NH}_{2}^{+}\right)$(Angelino et al., 2001; Pratt et al., 2009; Rehbein et al., 2011; Zhang et al., 2012; Healy et al., 2014a). We observed a particle type with the abundance of $m / z 59$ and to a lesser degree also $m / z 74$ (Fig. 2) that we interpret as organic particles that contain amines. In addition, the fragmentation patterns of several single particle mass spectra show peaks at $m / z 86$ $\left(\left(\mathrm{C}_{2} \mathrm{H}_{5}\right)_{2} \mathrm{NCH}_{2}^{+}\right)$and $m / z 101$ (molecular peak of trimethy-
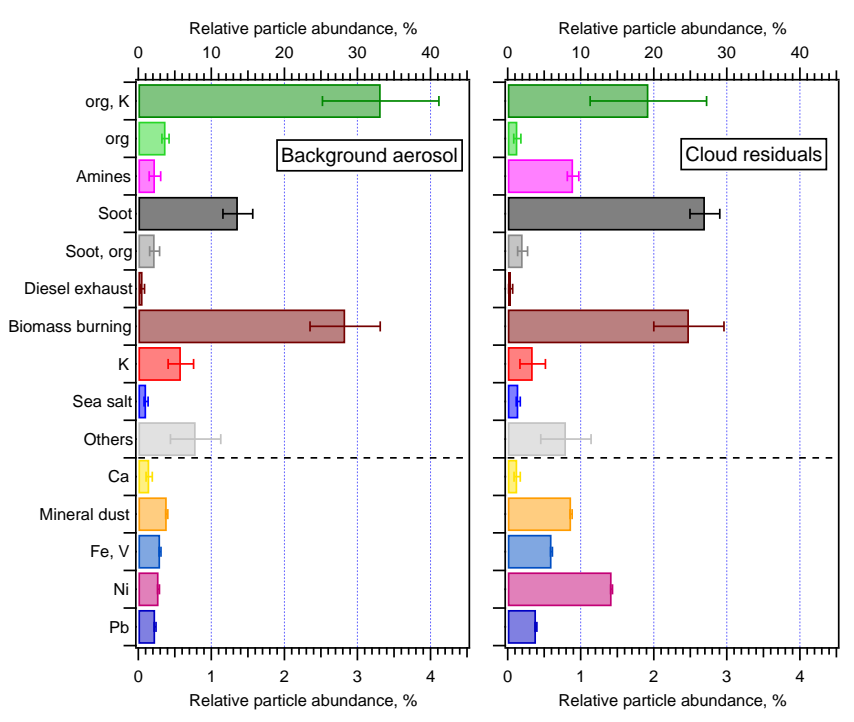

Figure 6. Aerosol composition of out-of-cloud aerosol (left) and cloud residual particles (right) for the entire HCCT-2010 campaign. Uncertainties of the clustering were estimated according to Sect. 2.4.2. In case of particle types determined by the marker peak method (Sect. 2.4.3) uncertainties are based on Poisson statistic. Number of analysed particles: out-of-cloud aerosol: 164 595, cloud residues: 13157 . Note that the scale is expanded by a factor of 10 below the dashed line (bottom axis), particle abundances above the dashed line refer to the top axis.

lamine, TMA) indicating detection of TMA (Angelino et al., 2001). Interestingly, the relative fraction of mass spectra that contain signatures for amines is increased in the cloud residues (Fig. 6). Thus, the time series of the characteristic marker peak $m / z 59$ was compared to the concentrations of TMA, dimethylamine (DMA), and methylamine (MA) measured in the cloud water samples by ion chromatography (Fig. 7). Caution is required because cobalt is an isobar to the amine fragment $\left(\mathrm{CH}_{3}\right)_{3} \mathrm{~N}^{+}$at $m / z 59$. But since cobalt was 


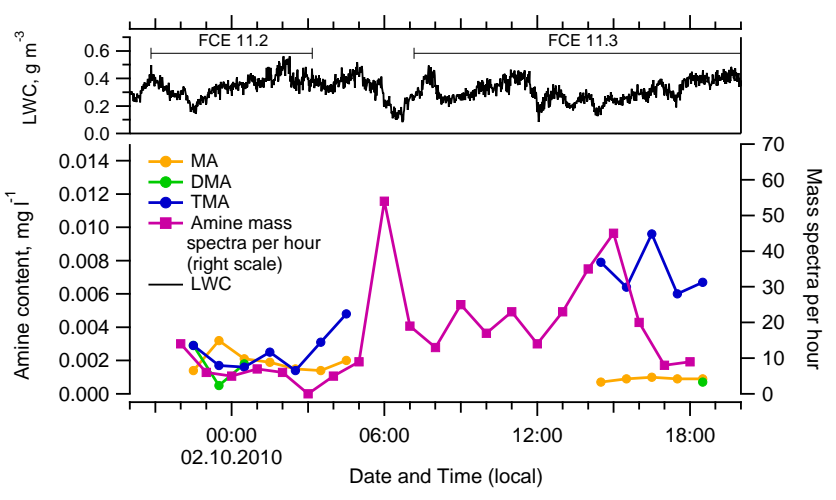

Figure 7. Time series (LT) of the amine compounds methylamine (MA), dimethylamine (DMA), and trimethylamine (TMA) from cloud water samples on 2 October 2010 (FCE11.2 and FCE 11.3) compared to the time series (number of mass spectra per hour) of amine-containing cloud residues. The upper panel shows the liquid water content (LWC) and the FCE times.

detected during HCCT-2010 only in very low concentration in the cloud water samples (Fomba et al., 2015), we ascribe the signal at $m / z 59$ to amine compounds. Due to the fact that cloud water sampling was not done continuously, the time series of ALABAMA and the amine species are only partly comparable. A reasonably good agreement is observed between the number of amine containing mass spectra per hour and the mass concentration of TMA (Pearson's $r=0.60$ ) except for the disagreement around 17:00. Amine compounds in the atmosphere can originate from various sources (Ge et al., 2011). Other than from animal husbandry and biomass burning (Schade and Crutzen, 1995), TMA, DMA, and MA can originate from, e.g. industrial processes (Ge et al., 2011) and have been observed in ambient air (Chang et al., 2003; Sellegri et al., 2005). An enhanced partitioning for gas phase TMA on pre-existing particles coated by an aqueous layer was observed at high relative humidity and low temperature (Rehbein et al., 2011; Zhang et al., 2012); thus the generally increased abundance of amines in cloud water may not be surprising. Whether amines remain in the aerosol phase after cloud droplet evaporation remains unclear, but may play an important role in cloud processing of aerosol particles.

\subsubsection{Biomass burning and soot}

The results also show an increased fraction of the particle type "soot" in cloud residues. Freshly emitted soot particles are hydrophobic and do not serve as CCN at realistic supersaturations (Dusek et al., 2006a; Koehler et al., 2009). Nevertheless, it was observed in several studies that soot is more efficiently activated than organic particles (Hitzenberger et al., 2000; Sellegri et al., 2003). The size-resolved aerosol composition (see Fig. 3) shows that the observed "soot" particles were mainly larger than $450 \mathrm{~nm}$, leading to the conclusion that mostly aged soot particles were analysed by the mass spectrometer. Furthermore, the "soot" clusters reveal internal mixtures with soluble inorganic compounds like nitrate or sulfate, which is presumably leading to activation of these particles at lower critical supersaturation (Dusek et al., 2006a; Henning et al., 2010). Internally mixed particles can either develop from condensation of secondary compounds on pre-existing particles or from coagulation with hygroscopic particles, or cloud droplets. Due to the fact that even the out-of-cloud aerosol particles that contain soot are internally mixed with secondary inorganic compounds, the increased fraction of soot particles in cloud residues can rather be explained by a good CCN activity of hygroscopic soot particles than caused by in-cloud impaction scavenging. Aging of atmospheric soot particles by coating with sulfate and nitrate has been observed using single particle mass spectrometry by Pratt and Prather (2010) as well as by Moffet and Prather (2009). The authors concluded that such processing of soot particles in the urban environment of Mexico City takes about 3 hours. Although in a cleaner environment than Mexico City coating by nitrate and sulfate will likely be slower, it appears to be a reasonable explanation for the findings that soot-containing particles internally mixed with nitrate and sulfate are efficiently activated as CCN and are therefore enhanced in cloud residues. Similar findings have been reported for growth factors of coated black carbon particles measured in Paris using a hygroscopic tandem differential mobility analyser and a single particle mass spectrometer (Healy et al., 2014b). The mass-based scavenging efficiency of soot particles in our study was found to be markedly lower than that of sulfate or nitrate (Schneider et al., 2016), confirming the assumption that the large soot-containing particles $(>450 \mathrm{~nm})$ found in the cloud residues contain soot only as a minor mass fraction.

The relative percentage of biomass burning particles occurring in the out-of-cloud aerosol does not differ much from that in the cloud residues. In agreement with previous observations (Ross et al., 2003; de Villiers et al., 2010) this implies that aerosol from biomass burning is an effective CCN, resulting from a high content of soluble organic and inorganic compounds in the particles (Silva et al., 1999; Posfai et al., 2003; Andreae and Rosenfeld, 2008; Pratt et al., 2011).

The high percentage of particles originating from combustion processes ("soot", "biomass burning", "diesel exhaust") of about $43 \%$ (Fig. 6) is investigated more closely in the following. Figure 8 shows the time series of the particle types "soot" (blue, Fig. 8b) and the sum of all particle types containing elemental carbon (brown, Fig. 8c) observed by ALABAMA, along with temperature, concentration of equivalent black carbon (EBC) measured by the MAAP, and the biomass burning aerosol inferred from AMS data (green, Fig. 8d). The latter was estimated from the AMS data based on the marker peak at $m / z 60$ for Levoglucosan, which is an indicator for biomass burning (Simoneit et al., 1999; Schneider et al., 2006; Alfarra et al., 2007). Conversion of $f_{60}$ (fraction of $m / z 60$ in the total organic signal) into mass concen- 


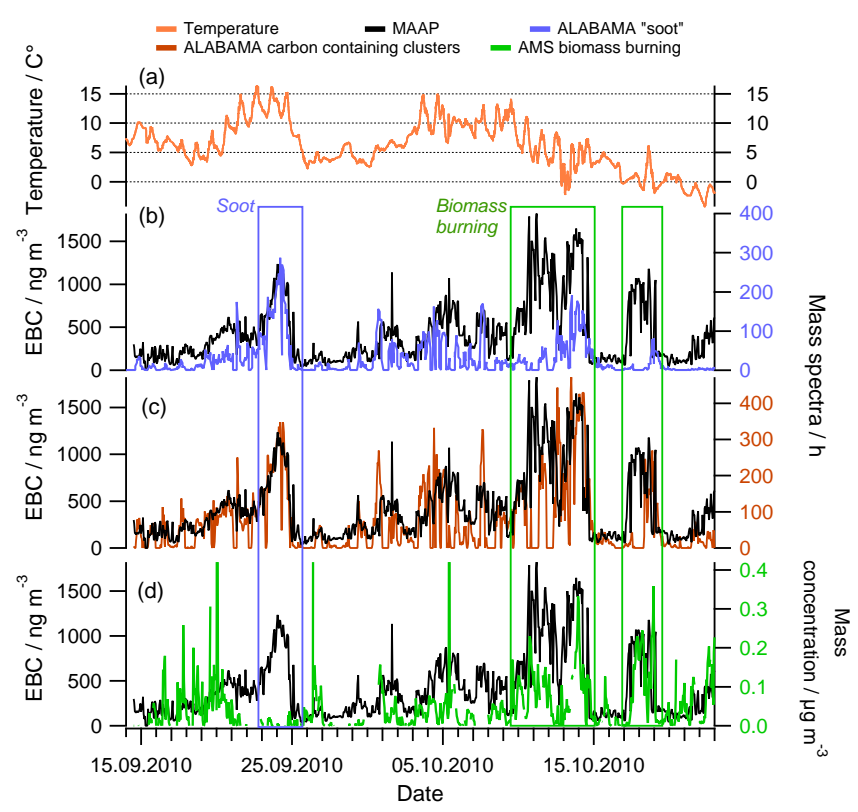

Figure 8. Time series (local time) of combustion-related parameters observed during HCCT-2010. (a) Temperature, (b) equivalent black carbon (EBC) together with the particle type "soot" (blue), (c) EBC along with the particle type biomass burning (brown), (d) EBC along with the biomass burning aerosol inferred from AMS data (green).

tration was demonstrated by Weimer (2008) and Crippa et al. (2014). The time series of the "soot" particle type agrees only partly with the time series of EBC. A better agreement $(r=0.47)$ is reached if the time series of all clusters containing elemental carbon in the mean mass spectra ("soot", "diesel exhaust", "biomass burning") is compared to EBC. The three data sets (MAAP, ALABAMA, AMS) allow for the attribution of the events shown in Fig. 8 with enhanced EBC concentrations to different particle types: the event on 24 September 2010 (blue frame) is not caused by biomass burning but from combustion of other (most likely fossil) fuel (like coal, oil, diesel), because the biomass burning marker remains low. In contrast, the events from 10 to 15 October 2010 and from 17 to 19 October 2010 (green frame) can be mainly attributed to biomass burning. The short data gap on 17 October is due to technical issues. Furthermore, the EBC concentration and the percentage of biomass burning particles rise with decreasing temperature (Fig. 8a). This can be attributed to the beginning of heating period and consequently increased heating after 1 October 2010 leading to increased emission of from local and regional residential heating in the city Suhl and other smaller cities and villages in south-westerly direction (compare also Sect. 3.3).

\subsubsection{Mineral dust and metals}

Except for the particle type "Ca", the number fractions of mineral dust and metallic particle types ("Fe, V", "Ni", and
" $\mathrm{Pb}$ ") are markedly enhanced in the cloud residues. All these particles contain nitrate and sulfate, too (see Fig. 2); thus, the good activation or scavenging efficiency is likely caused by the soluble compounds in these particles. The presence of metals in cloud droplets has important implications for the oxidation of sulfur-containing species in the aqueous phase. Catalytic oxidation of $\mathrm{SO}_{2}$ to sulfate by transition metals as Fe and Mn (Calvert et al., 1985), but also Ti (Harris et al., 2013) and V (Ault et al., 2010) is a process that has long been recognised (Calvert et al., 1985; Bradbury et al., 1999), but data obtained during HCCT2010 have shown that this process is of higher importance than previously thought (Harris et al., 2013). In marine environments, dimethyl sulfide can be catalytically oxidised by vanadium to methanesulfonic acid (Gaston et al., 2010). Enrichment of these transition metals in cloud droplets may be explained by cloud processing: transition metal-catalysed sulfate production in the cloud droplets leads to a higher sulfate content of the metalcontaining aerosol particles remaining after cloud evaporation and thereby to a better activation of these particles in the next cloud formation process.

\subsection{Cloud residue analysis for the full cloud events}

In the following the selected FCEs (see Table 1) will be analysed in more detail. These cloud events represent a subset of all cloud measurements and are referring to certain conditions that were given in detail in Tilgner et al. (2014). The composition of the cloud residual particles measured during the individual FCE during HCCT-2010 are shown in Fig. 9. Also given are the number of analysed mass spectra and the averaged mass concentration of equivalent black carbon measured in the interstitial aerosol during the events. Only FCE with sufficient ( $>100$ ) number of mass spectra are considered. These individual events show large event-to-event variability, especially in the fraction of particles of the type "soot". Four FCE are characterised by a markedly higher fraction of "soot" particles, namely FCE 7.1, 11.2, 11.3, and 13.3, all of them between 24 September and 6 October. These events are also characterised by a high absolute mass concentration of EBC, especially FCE 11.2 and FCE 13.3 with about $300 \mathrm{ng} \mathrm{m}^{-3}$ of EBC. To further investigate this finding, the origin of the air masses encountered during these FCE is inspected by means of back trajectories. Figure 10 displays the $96 \mathrm{~h}$ back trajectories, separated for the "low-soot FCE" (left) and the "high-soot FCE" (right). It becomes clear that the air masses encountered during the "low-soot FCE" arrive mainly from west/north-west and have spent a considerable amount of the $96 \mathrm{~h}$ prior to the measurement over the Atlantic Ocean (see also Fig. S1 in the Supplement to Tilgner et al., 2014). These air masses had less opportunity to accumulate pollution particles over the continent. In contrast, the "high-soot" air masses arrive more from south/south-west and have travelled slower, therefore having spent more of the previous $96 \mathrm{~h}$ over land, leading to higher accumulation of anthropogenic 


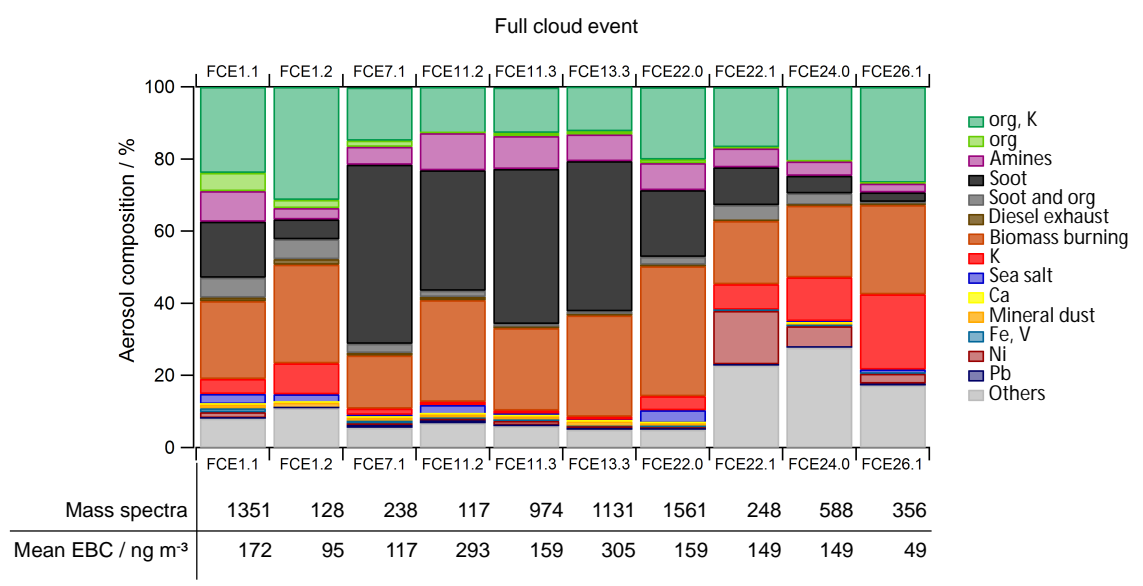

Figure 9. Cloud residue composition during full cloud events (FCE). The number of obtained single particle mass spectra and the mean EBC concentration per event is given below the graph. Only FCE with more than 100 mass spectra are included (see Table 1).
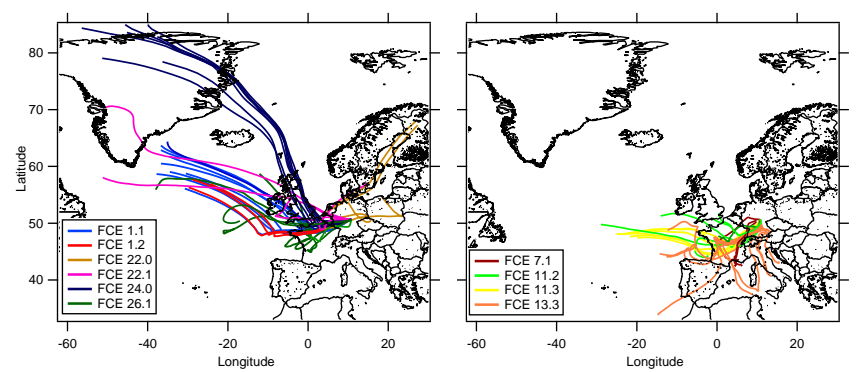

Figure 10. HYSPLIT back trajectories (96h) for air masses encountered during the FCE displayed in Fig. 9. Left: FCE with low soot particle abundance; right: FCE with high soot particle abundance. Trajectory end point: Schmücke $\left(10^{\circ} 46^{\prime} 15^{\prime \prime}\right.$ E, $50^{\circ} 39^{\prime} 19^{\prime \prime} \mathrm{N} ; 500 \mathrm{~m}$ above model ground level). Temporal difference between successive trajectories: $2 \mathrm{~h}$.

emitted particles like soot. An exceptional case is FCE 22.0 (included in the left graph of Fig. 10), where the air masses arrive from east/north-east, although the local wind direction was south-west (as a prerequisite for an FCE). This air mass contained the highest fraction of biomass burning particles of all FCE and the highest number of mass spectra per event and time (1561 spectra in only $7.2 \mathrm{~h}$, see Table 1 ). It has to be noted here that the full cloud events may not be representative for the general situation for clouds at the Schmücke, because of the selected data set. The composition data for the FCE are based on 4400 mass spectra, while for the composition of all cloud residues (Fig. 6) more than 13000 mass spectra were analysed. For example, the required prerequisite that the local wind direction for an FCE has to be south-west, air masses of all FCE pass the city of Suhl located south-west of the Schmücke, which may lead to a higher relative amount of anthropogenic particles and a higher influence of local and regional emissions in the full cloud events compared to the general case. On the other hand, the analysis of the diurnal cycles in Sect. 3.1 has shown that in general local and regional sources have a high influence on the aerosol particle abundance.

\subsection{Change of particle mixing state by cloud processing}

As mentioned before, all identified particle types indicate internal mixtures with nitrate, sulfate, or both species. Therefore, the clustering algorithm cannot provide information about the mixing state of the particles from out-of-cloud to inside of the cloud. Therefore, the mixing state of the particles with nitrate and sulfate was investigated by means of the characteristic marker peaks $m / z-62\left(\mathrm{NO}_{3}^{-}\right)$and $m / z-97$ $\left(\mathrm{HSO}_{4}^{-}\right.$).

To compare cloud residues and out-of-cloud aerosol, we selected air masses with comparable origins based on HYSPLIT back trajectories for in-cloud and out-of-cloud conditions. As an additional criterion it was required that the local wind direction at the Schmücke was constant. The listed events "I" and "II" in Table 5 fulfilled these criteria. These events differ slightly from the defined FCEs because the criteria for the FCEs were not taken into account here. The cloud sampling phase of event "I" corresponds mostly to FCE1.1, while that of event "II" is a part of FCE24.0. During event "I" the air masses for in-cloud and out-of-cloud conditions both arrived from France, while air masses for both conditions during event "II" passed over England.

The characteristic marker peaks $m / z-62$ and $m / z-97$ in the single particle mass spectra of the events "I" and "II" show that only less than $1 \%$ of the out-of-cloud aerosol particles contained neither nitrate nor sulfate for both events. Thus, $99 \%$ of the out-of-cloud aerosol particles were already internally mixed with secondary inorganic compounds before passing the cloud. Such a high percentage of particles being internally mixed with secondary inorganic compounds were also found by single particle mass spectrometry dur- 
Table 5. Cloud and out-of-cloud periods (local time) used for the investigation of the mixing state of the particles.

\begin{tabular}{|c|c|c|c|c|c|c|}
\hline Event & start & $\begin{array}{l}\text { it-of-cloud aerosol } \\
\text { end }\end{array}$ & mass spectra & start & $\begin{array}{l}\text { Cloud residues } \\
\text { end }\end{array}$ & mass spectra \\
\hline I & $15-09-2010,11: 00$ & $15-09-2010,23: 30$ & 1732 & $14-09-2010,11: 00$ & $15-09-2010,02: 00$ & 1351 \\
\hline II & $21-10-2010,14: 15$ & $21-10-2010,22: 15$ & 1410 & $21-10-2010,23: 24$ & $22-10-2010,09: 29$ & 577 \\
\hline
\end{tabular}
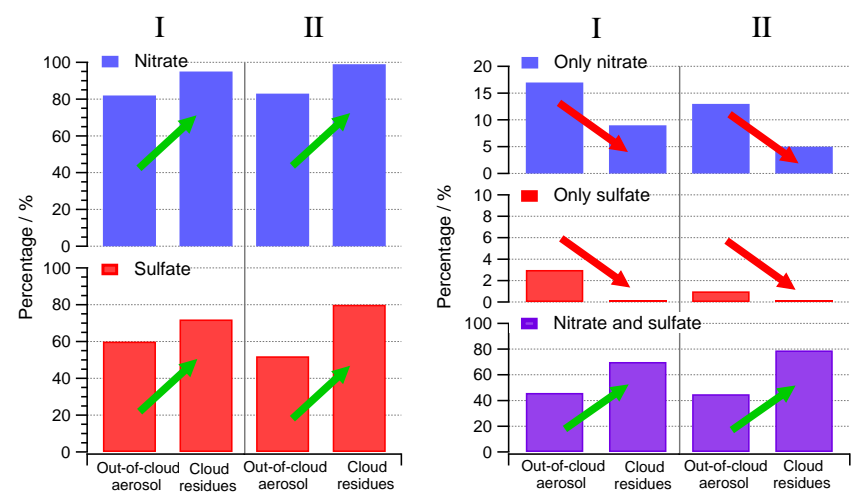

Figure 11. Indications for a change of the mixing state of the particles in the cloud (for details of event I and II see Table 5). Left: percentage of out-of-cloud aerosol particles and cloud residues containing either nitrate (blue) or sulfate (red). Right: particles containing only nitrate but no sulfate (blue), only sulfate but no nitrate (red), and particles containing both nitrate and sulfate (purple).

ing other studies in California (Cahill et al., 2012) or Harrow (Jeong et al., 2011). However, we observed an increase of the particle fraction containing nitrate in the cloud residues compared to the out-of-cloud aerosol, and the same finding holds for sulfate (Fig. 11, left). This can be explained by a more detailed analysis of the mixing state of the particles, distinguishing between particles containing only nitrate, only sulfate or both nitrate and sulfate (Fig. 11, right). Particles internally mixed only with sulfate (i.e. containing no nitrate) represent in general a minor fraction $(<3 \%)$. For both analysed events the percentage of particles containing only nitrate and only sulfate was smaller in case of cloud residues compared to the out-of-cloud aerosol while the percentage of particles with nitrate and sulfate was increased. This observed increase indicates a sulfate addition to those particles that contained only nitrate, but also a nitrate addition to those particles that contained only sulfate. In the cloud residues, particles not containing nitrate can almost not be found. It must be noted that relative percentages of out-ofcloud aerosol particles internally mixed with secondary inorganics added for both events are less than the $99 \%$ inferred above, due to the different threshold values that had to be used for the definition whether a peak is present in a mass spectrum or not (see Supplement, Sect. S3). This addition of sulfate and nitrate (and possibly also of organic components as amines, see Sect. 3.2.2) by cloud processing can also be

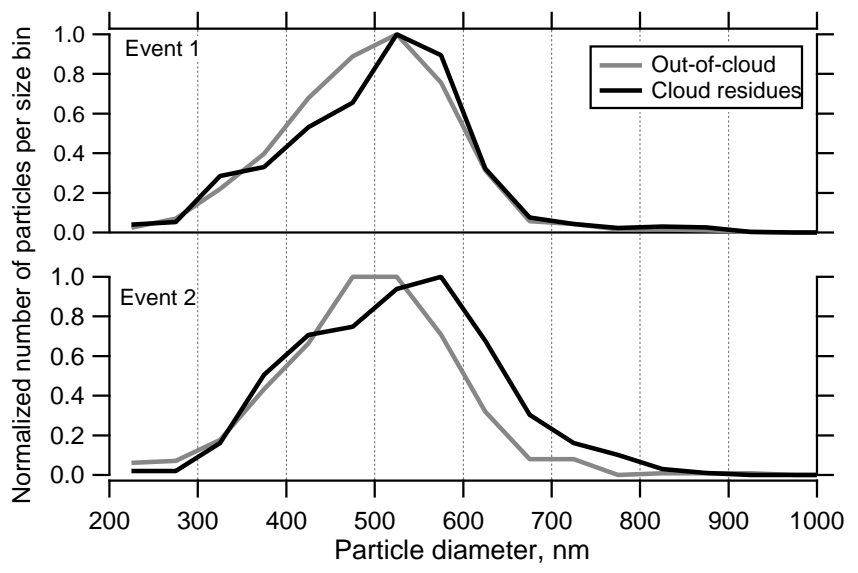

Figure 12. Histograms of particles analysed by ALABAMA during event I and event II (Table 5). In both cases the histograms are shifted to larger sizes for the cloud residues, indicating the uptake of gaseous compounds by the cloud droplets leading to an increased size of the cloud residual particles compared to the out-of-cloud particles measured shortly before cloud formation.

observed in a size shift of the analysed particles. Figure 12 shows the size histograms of the particles analysed by ALABAMA during event I and II. In both cases a shift in the histogram to larger sizes is observed. The activation of $\mathrm{CCN}$ to cloud droplets is usually occurring at much smaller sizes (activation diameters upwind of the Schmücke have been observed to range between 123 and $194 \mathrm{~nm}$; Henning et al., 2014), such that the observed size shift by ALABAMA can very likely be attributed to the uptake of gaseous species by the cloud droplets, leading to a size increase of the residual particles.

These two case studies demonstrate the change of the mixing state of the particles by chemical processes inside the cloud liquid phase. Similar observations were found earlier in numerous studies (e.g. Laj et al., 1997b; Sellegri et al., 2003; Brüggemann et al., 2005; McFiggans et al., 2006; Hayden et al., 2008; Zelenyuk et al., 2010). The enrichment of nitrate was also observed by simultaneous measurements with an AMS providing evidence of an increased mass concentration of nitrate in cloud residues compared to interstitial and out-of-cloud aerosol (Schneider et al., 2016). Such an enhancement of nitrate in cloud droplets can be explained by the uptake of gaseous nitric acid into the cloud droplets (Tilgner et al., 2005; Hayden et al., 2008). Enrichment of 
sulfate in cloud droplets can occur via different pathways. Besides the uptake of gaseous $\mathrm{H}_{2} \mathrm{SO}_{4}$ and the scavenging of ultrafine particulate matter also the uptake of $\mathrm{SO}_{2}$ with subsequent oxidation plays a role (Harris et al., 2014). Furthermore Harris et al. (2013) could prove that besides the known $\mathrm{SO}_{2}$ oxidation by $\mathrm{H}_{2} \mathrm{O}_{2}$ also the oxidation with $\mathrm{O}_{2}$ catalysed by transition metals plays a significant role in sulfate production. Despite the low number concentration of activated mineral dust particles in general, it became apparent that $\mathrm{SO}_{2}$ oxidation was mainly catalysed by dissolved transition metals during HCCT-2010. As it was shown in this study, transition metals were also detected by the ALABAMA (see Table 2).

Furthermore, the aerosol hygroscopicity was investigated in the same field experiment before and after cloud formation at the valley sites. In agreement with the described results, the hygroscopicity of the particles was found to be increased after passing the cloud (up to $50 \%$, see Henning et al. (2014). By means of the above described processes, water-soluble material is enriched inside the particles while being processed by the cloud. After evaporation of the cloud the water-soluble material it is likely to remain in the particles, thereby increasing their hygroscopicity. This process will occur in all cloud droplets formed from all CCN sizes, and therefore also influence the $\mathrm{CCN}$ properties of aerosol particles smaller than analysed here. For small aerosol particles that are in the size range of the activation diameter for a specific supersaturation the chemical composition plays an important role for the activation.

\section{Summary and conclusions}

During the HCCT-2010 campaign, more than 170000 aerosol particles and more than 14000 cloud residual particles were analysed by single particle mass spectrometry. The data evaluation was done by a combination of the clustering algorithm fuzzy $c$-means and the marker peak method, resulting in 14 different particle types. From the diurnal trends of the occurrence of these particle types, the influence of local and regional sources on the aerosol composition was estimated to be about $63 \%$. Especially the particle types "soot" and "biomass burning" could be allocated to local or regional sources. The single particle data further allowed for a better attribution of equivalent black carbon to different sources, as fossil fuel burning or biomass burning. Important local sources are the city Suhl in the predominant wind direction, together with the beginning of the heating period in October, leading to increased biomass burning signatures.

Analysis of the cloud residues revealed that the relative percentage of soot and amines is increased compared to outof-cloud aerosol. Analysis of cloud water samples by ion chromatography showed that amines were mainly found in the form of trimethylamine. The increased fraction of soot can be explained by processing of soot particles leading to coating by nitrate and sulfate, which is known to occur in a few hours. In addition the size-resolved aerosol composition reveals that the detected particles containing soot are larger than $450 \mathrm{~nm}$. Both facts suggest that such processed soot particles are good cloud condensation nuclei.

All observed particle types show internal mixtures with the secondary inorganic compounds nitrate and/or sulfate. By means of the characteristic marker peaks $m / z-62$ and $m / z-97$ for nitrate and sulfate, respectively, the change of the mixing state of the particles from out-of-cloud to in-cloud was investigated in two case studies. In both cases the addition of nitrate and sulfate to the cloud droplets was observed. This finding is most likely due to the uptake of $\mathrm{HNO}_{3}$ from the gas phase and sulfate production by the oxidation of $\mathrm{SO}_{2}$ by transition metals and $\mathrm{H}_{2} \mathrm{O}_{2}$ inside the cloud droplets (Harris et al., 2014), besides the uptake of $\mathrm{H}_{2} \mathrm{SO}_{4}$.

Such a cloud processing of aerosol particles has important implications for the hygroscopic properties of the aerosol particles after cloud passage. An increase of soluble compounds in the particles, together with the involved growth of the particle size, will lead to an enhanced number of CCN that are available in the air mass after evaporation of the cloud. Additionally the modified chemical composition can lead to altered radiation properties concerning light scattering and absorption. Especially internal mixed soot particles indicate a higher absorption than pure soot particles (Jacobson, 2001) and could therefore counteract the cooling effect of clouds.

\section{The Supplement related to this article is available online at doi:10.5194/acp-16-505-2016-supplement.}

Acknowledgements. The German Research Foundation DFG funded the participation of S. Mertes (grant HE 939/25-1 and ME 3534/1-2).

We thank Thomas Böttger, Wilhelm Schneider, Paul Reitz, Jovana Diesch, Sarah-Lena von der Weiden-Reinmüller, and Friederike Freutel for the support at the measurement site as well as Frank Helleis for electrical and technical advices and the whole HCCT-2010 team.

The article processing charges for this open-access publication were covered by the Max Planck Society

Edited by: M. C. Facchini 


\section{References}

Alfarra, M. R., Prevot, A. S. H., Szidat, S., Sandradewi, J., Weimer, S., Lanz, V. A., Schreiber, D., Mohr, M., and Baltensperger, U.: Identification of the mass spectral signature of organic aerosols from wood burning emissions, Environ. Sci. Technol., 41, 57705777, doi:10.1021/es062289b, 2007.

Allan, J. D., Baumgardner, D., Raga, G. B., Mayol-Bracero, O. L., Morales-García, F., García-García, F., Montero-Martínez, G., Borrmann, S., Schneider, J., Mertes, S., Walter, S., Gysel, M., Dusek, U., Frank, G. P., and Krämer, M.: Clouds and aerosols in Puerto Rico - a new evaluation, Atmos. Chem. Phys., 8, 12931309, doi:10.5194/acp-8-1293-2008, 2008.

Andreae, M. O. and Rosenfeld, D.: Aerosol-cloudprecipitation interactions. Part 1. The nature and sources of cloud-active aerosols, Earth-Sci. Rev., 89, 13-41, doi:10.1016/j.earscirev.2008.03.001, 2008.

Angelino, S., Suess, D. T., and Prather, K. A.: Formation of aerosol particles from reactions of secondary and tertiary alkylamines: Characterization by aerosol time-of-flight mass spectrometry, Environ. Sci. Technol., 35, 3130-3138, doi:10.1021/es0015444, 2001.

Ault, A. P., Moore, M. J., Furutani, H., and Prather, K. A.: Impact of Emissions from the Los Angeles Port Region on San Diego Air Quality during Regional Transport Events, Environ. Sci. Technol., 43, 3500-3506, doi:10.1021/es8018918, 2009.

Ault, A. P., Gaston, C. J., Wang, Y., Dominguez, G., Thiemens, M. H., and Prather, K. A.: Characterization of the Single Particle Mixing State of Individual Ship Plume Events Measured at the Port of Los Angeles, Environ. Sci. Technol., 44, 1954-1961, doi:10.1021/es902985h, 2010.

Bein, K. J., Zhao, Y. J., Wexler, A. S., and Johnston, M. V.: Speciation of size-resolved individual ultrafine particles in Pittsburgh, Pennsylvania, J. Geophys. Res.-Atmos., 110, D07S05, doi:10.1029/2004jd004708, 2005.

Bezdek, J. C.: Pattern Recognition with Fuzzy Objective Function Algorithms, Plenum Press, New York, 1981.

Bezdek, J. C., Ehrlich, R., and Full, W.: FCM - The fuzzy c-means clustering-algorithm, Comput. Geosci., 10, 191-203, doi:10.1016/0098-3004(84)90020-7, 1984.

Bower, K. N., Hill, T. A., Coe, H., and Choularton, T. W.: SO2 oxidation in an entraining cloud model with explicit microphysics, Atmos. Environ. Pt a, 25, 2401-2418, doi:10.1016/09601686(91)90114-m, 1991.

Bower, K. N., Choularton, T. W., Gallagher, M. W., Colvile, R. N., Wells, M., Beswick, K. M., Wiedensohler, A., Hansson, H. C., Svenningsson, B., Swietlicki, E., Wendisch, M., Berner, A., Kruisz, C., Laj, P., Facchini, M. C., Fuzzi, S., Bizjak, M., Dollard, G., Jones, B., Acker, K., Wieprecht, W., Preiss, M., Sutton, M. A., Hargreaves, K. J., Storeton-West, R. L., Cape, J. N., and Arends, B. G.: Observations and modelling of the processing of aerosol by a hill cap cloud, Atmos. Environ., 31, 2527-2543, doi:10.1016/S1352-2310(96)00317-2, 1997.

Bradbury, C., Bower, K. N., Choularton, T. W., Swietlicki, E., Birmili, W., Wiedensohler, A., Yuskiewicz, B., Berner, A., Dusek, U., Dore, C., and McFadyen, G. G.: Modelling of aerosol modification resulting from passage through a hill cap cloud, Atmos. Res., 50, 185-204, doi:10.1016/S0169-8095(98)00104-5, 1999.

Brands, M., Kamphus, M., Böttger, T., Schneider, J., Drewnick, F., Roth, A., Curtius, J., Voigt, C., Borbon, A., Beekmann,
M., Bourdon, A., Perrin, T., and Borrmann, S.: Characterization of a Newly Developed Aircraft-Based Laser Ablation Aerosol Mass Spectrometer (ALABAMA) and First Field Deployment in Urban Pollution Plumes over Paris During MEGAPOLI 2009, Aerosol Sci. Technol., 45, 46-64, doi:10.1080/02786826.2010.517813, 2011.

Brüggemann, E., Gnauk, T., Mertes, S., Acker, K., Auel, R., Wieprecht, W., Moller, D., Collett, J. L., Chang, H., Galgon, D., Chemnitzer, R., Rud, C., Junek, R., Wiedensohler, W., and Herrmann, H.: Schmucke hill cap cloud and valley stations aerosol characterisation during FEBUKO (I): Particle size distribution, mass, and main components, Atmos. Environ., 39, 4291-4303, doi:10.1016/j.atmosenv.2005.02.013, 2005.

Cahill, J. F., Suski, K., Seinfeld, J. H., Zaveri, R. A., and Prather, K. A.: The mixing state of carbonaceous aerosol particles in northern and southern California measured during CARES and CalNex 2010, Atmos. Chem. Phys., 12, 10989-11002, doi:10.5194/acp-12-10989-2012, 2012.

Calvert, J. G., Lazrus, A., Kok, G. L., Heikes, B. G., Walega, J. G., Lind, J., and Cantrell, C. A.: Chemical mechanisms of acid generation in the troposphere, Nature, 317, 27-35, doi:10.1038/317027a0, 1985.

Chang, I. H., Lee, C. G., and Lee, D. S.: Development of an automated method for simultaneous determination of low molecular weight aliphatic amines and ammonia in ambient air by diffusion scrubber coupled to ion chromatography, Anal. Chem., 75, 6141-6146, doi:10.1021/ac0347314, 2003.

Corbin, J. C., Rehbein, P. J. G., Evans, G. J., and Abbatt, J. P. D.: Combustion particles as ice nuclei in an urban environment: Evidence from single-particle mass spectrometry, Atmos. Environ., 51, 286-292, doi:10.1016/j.atmosenv.2012.01.007, 2012.

Crippa, M., DeCarlo, P. F., Slowik, J. G., Mohr, C., Heringa, M. F., Chirico, R., Poulain, L., Freutel, F., Sciare, J., Cozic, J., Di Marco, C. F., Elsasser, M., Nicolas, J. B., Marchand, N., Abidi, E., Wiedensohler, A., Drewnick, F., Schneider, J., Borrmann, S., Nemitz, E., Zimmermann, R., Jaffrezo, J.-L., Prévôt, A. S. H., and Baltensperger, U.: Wintertime aerosol chemical composition and source apportionment of the organic fraction in the metropolitan area of Paris, Atmos. Chem. Phys., 13, 961-981, doi:10.5194/acp-13-961-2013, 2013.

Crippa, M., Canonaco, F., Lanz, V. A., Äijälä, M., Allan, J. D., Carbone, S., Capes, G., Ceburnis, D., Dall'Osto, M., Day, D. A., DeCarlo, P. F., Ehn, M., Eriksson, A., Freney, E., Hildebrandt Ruiz, L., Hillamo, R., Jimenez, J. L., Junninen, H., Kiendler-Scharr, A., Kortelainen, A.-M., Kulmala, M., Laaksonen, A., Mensah, A. A., Mohr, C., Nemitz, E., O’Dowd, C., Ovadnevaite, J., Pandis, S. N., Petäjä, T., Poulain, L., Saarikoski, S., Sellegri, K., Swietlicki, E., Tiitta, P., Worsnop, D. R., Baltensperger, U., and Prévôt, A. S. H.: Organic aerosol components derived from 25 AMS data sets across Europe using a consistent ME-2 based source apportionment approach, Atmos. Chem. Phys., 14, 61596176, doi:10.5194/acp-14-6159-2014, 2014.

Dall'Osto, M. and Harrison, R. M.: Chemical characterisation of single airborne particles in Athens (Greece) by ATOFMS, Atmos. Environ., 40, 7614-7631, doi:10.1016/j.atmosenv.2006.06.053, 2006.

Dall'Osto, M., Beddows, D. C. S., Kinnersley, R. P., Harrison, R. M., Donovan, R. J., and Heal, M. R.: Characterization of individual airborne particles by using aerosol time-of-flight mass spec- 
trometry at Mace Head, Ireland, J. Geophys. Res.-Atmos., 109, D21302, doi:10.1029/2004jd004747, 2004.

Dall'Osto, M., Harrison, R. M., Coe, H., Williams, P. I., and Allan, J. D.: Real time chemical characterization of local and regional nitrate aerosols, Atmos. Chem. Phys., 9, 3709-3720, doi:10.5194/acp-9-3709-2009, 2009.

Dall'Osto, M., Harrison, R. M., Highwood, E. J., O’Dowd, C., Ceburnis, D., Querol, X., and Achterberg, E. P.: Variation of the mixing state of Saharan dust particles with atmospheric transport, Atmos. Environ., 44, 3135-3146, doi:10.1016/j.atmosenv.2010.05.030, 2010.

DeCarlo, P. F., Kimmel, J. R., Trimborn, A., Northway, M. J., Jayne, J. T., Aiken, A. C., Gonin, M., Fuhrer, K., Horvath, T., Docherty, K. S., Worsnop, D. R., and Jimenez, J. L.: Field-deployable, high-resolution, time-of-flight aerosol mass spectrometer, Anal. Chem., 78, 8281-8289, doi:10.1021/ac061249n, 2006.

de Villiers, R. A., Ancellet, G., Pelon, J., Quennehen, B., Schwarzenboeck, A., Gayet, J. F., and Law, K. S.: Airborne measurements of aerosol optical properties related to early spring transport of mid-latitude sources into the Arctic, Atmos. Chem. Phys., 10, 5011-5030, doi:10.5194/acp-10-5011-2010, 2010.

Draxler, R. R. and Rolph, G. D.: HYSPLIT (HYbrid Single-Particle Lagrangian Integrated Trajectory) Model access via NOAA ARL READY Website, available at: http://ready.arl.noaa.gov/ HYSPLIT.php, NOAA Air Resources Laboratory, Silver Spring, MD, 2012.

Drewnick, F., Hings, S. S., DeCarlo, P., Jayne, J. T., Gonin, M., Fuhrer, K., Weimer, S., Jimenez, J. L., Demerjian, K. L., Borrmann, S., and Worsnop, D. R.: A new time-of-flight aerosol mass spectrometer (TOF-AMS) - Instrument description and first field deployment, Aerosol Sci. Technol., 39, 637-658, doi:10.1080/02786820500182040, 2005.

Drewnick, F., Schneider, J., Hings, S. S., Hock, N., Noone, K., Targino, A., Weimer, S., and Borrmann, S.: Measurement of ambient, interstitial, and residual aerosol particles on a mountaintop site in central Sweden using an aerosol mass spectrometer and a CVI, J. Atmos. Chem., 56, 1-20, doi:10.1007/s10874-006-90368, 2007.

Dusek, U., Reischl, G. P., and Hitzenberger, R.: CCN Activation of Pure and Coated Carbon Black Particles, Environ. Sci. Technol., 40, 1223-1230, doi:10.1021/es0503478, 2006a.

Dusek, U., Frank, G. P., Hildebrandt, L., Curtius, J., Schneider, J., Walter, S., Chand, D., Drewnick, F., Hings, S., Jung, D., Borrmann, S., and Andreae, M. O.: Size matters more than chemistry for cloud-nucleating ability of aerosol particles, Science, 312, 1375-1378, 2006b.

Facchini, M. C., Decesari, S., Rinaldi, M., Carbone, C., Finessi, E., Mircea, M., Fuzzi, S., Moretti, F., Tagliavini, E., Ceburnis, D., and O'Dowd, C. D.: Important Source of Marine Secondary Organic Aerosol from Biogenic Amines, Environ. Sci. Technol., 42, 9116-9121, doi:10.1021/es8018385, 2008.

Fomba, K. W., van Pinxteren, D., Müller, K., Iinuma, Y., Lee, T., Collett Jr., J. L., and Herrmann, H.: Trace metal characterization of aerosol particles and cloud water during HCCT 2010, Atmos. Chem. Phys., 15, 8751-8765, doi:10.5194/acp-15-87512015, 2015.

Fuzzi, S., Facchini, M. C., Schell, D., Wobrock, W., Winkler, P., Arends, B. G., Kessel, M., Möls, J. J., Pahl, S., Schneider, T., Berner, A., Solly, I., Kruisz, C., Kalina, M., Fierlinger, H., Hall- berg, A., Vitali, P., Santoli, L., and Tigli, G.: Multiphase chemistry and acidity of clouds at Kleiner Feldberg, J. Atmos. Chem., 19, 87-106, doi:10.1007/BF00696584, 1994.

Gaston, C. J., Pratt, K. A., Qin, X., and Prather, K. A.: Real-Time Detection and Mixing State of Methanesulfonate in Single Particles at an Inland Urban Location during a Phytoplankton Bloom, Environ. Sci. Technol., 44, 1566-1572, doi:10.1021/es902069d, 2010.

Ge, X., Wexler, A. S., and Clegg, S. L.: Atmospheric amines - Part I. A review, Atmos. Environ., 45, 524-546, doi:10.1016/j.atmosenv.20doi:10.10.012, 2011

Gieray, R., Wieser, P., Engelhardt, T., Swietlicki, E., Hansson, H. C., Mentes, B., Orsini, D., Martinsson, B., Svenningsson, B., Noone, K. J., and Heintzenberg, J.: Phase partitioning of aerosol constituents in cloud based on single-particle and bulk analysis, Atmos. Environ., 31, 2491-2502, doi:10.1016/S13522310(96)00298-1, 1997.

Gunthe, S. S., King, S. M., Rose, D., Chen, Q., Roldin, P., Farmer, D. K., Jimenez, J. L., Artaxo, P., Andreae, M. O., Martin, S. T., and Pöschl, U.: Cloud condensation nuclei in pristine tropical rainforest air of Amazonia: size-resolved measurements and modeling of atmospheric aerosol composition and CCN activity, Atmos. Chem. Phys., 9, 7551-7575, doi:10.5194/acp-9-75512009, 2009.

Hallberg, A., Ogren, J. A., Noone, K. J., Okada, K., Heintzenberg, J., and Svenningsson, I. B.: The influence of aerosol particle composition on cloud droplet formation, J. Atmos. Chem., 19, 153-171, doi:10.1007/BF00696587, 1994.

Harris, E., Sinha, B., van Pinxteren, D., Tilgner, A., Fomba, K. W., Schneider, J., Roth, A., Gnauk, T., Fahlbusch, B., Mertes, S., Lee, T., Collett, J., Foley, S., Borrmann, S., Hoppe, P., and Herrmann, H.: Enhanced Role of Transition Metal Ion Catalysis During In-Cloud Oxidation of SO2, Science, 340, 727-730, doi:10.1126/science.1230911, 2013.

Harris, E., Sinha, B., van Pinxteren, D., Schneider, J., Poulain, L., Collett, J., D’Anna, B., Fahlbusch, B., Foley, S., Fomba, K. W., George, C., Gnauk, T., Henning, S., Lee, T., Mertes, S., Roth, A., Stratmann, F., Borrmann, S., Hoppe, P., and Herrmann, H.: In-cloud sulfate addition to single particles resolved with sulfur isotope analysis during HCCT-2010, Atmos. Chem. Phys., 14, 4219-4235, doi:10.5194/acp-14-4219-2014, 2014.

Hayden, K. L., Macdonald, A. M., Gong, W., Toom-Sauntry, D., Anlauf, K. G., Leithead, A., Li, S. M., Leaitch, W. R., and Noone, K.: Cloud processing of nitrate, J. Geophys. Res.-Atmos., 113, D18201, doi:10.1029/2007jd009732, 2008.

Healy, R., Evans, G., Murphy, M., Sierau, B., Arndt, J., McGillicuddy, E., O'Connor, I., Sodeau, J., and Wenger, J.: Single-particle speciation of alkylamines in ambient aerosol at five European sites, Anal. Bioanal. Chem., 407, 5899-5909, doi:10.1007/s00216-014-8092-1, 2014a.

Healy, R. M., Evans, G. J., Murphy, M., Jurányi, Z., Tritscher, T., Laborde, M., Weingartner, E., Gysel, M., Poulain, L., Kamilli, K. A., Wiedensohler, A., O'Connor, I. P., McGillicuddy, E., Sodeau, J. R., and Wenger, J. C.: Predicting hygroscopic growth using single particle chemical composition estimates, J. Geophys. Res.Atmos., 119, 9567-9577, doi:10.1002/2014JD021888, 2014b.

Henning, S., Wex, H., Hennig, T., Kiselev, A., Snider, J. R., Rose, D., Dusek, U., Frank, G. P., Poschl, U., Kristensson, A., Bilde, M., Tillmann, R., Kiendler-Scharr, A., Mentel, T. F., Walter, S., 
Schneider, J., Wennrich, C., and Stratmann, F.: Soluble mass, hygroscopic growth, and droplet activation of coated soot particles during LACIS Experiment in November (LExNo), J. Geophys. Res.-Atmos., 115, D11206, doi:10.1029/2009jd012626, 2010.

Henning, S., Dieckmann, K., Ignatius, K., Schäfer, M., Zedler, P., Harris, E., Sinha, B., van Pinxteren, D., Mertes, S., Birmili, W., Merkel, M., Wu, Z., Wiedensohler, A., Wex, H., Herrmann, H., and Stratmann, F.: Influence of cloud processing on CCN activation behaviour in the Thuringian Forest, Germany during HCCT2010, Atmos. Chem. Phys., 14, 7859-7868, doi:10.5194/acp-147859-2014, 2014.

Herrmann, H., Wolke, R., Muller, K., Bruggemann, E., Gnauk, T., Barzaghi, P., Mertes, S., Lehmann, K., Massling, A., Birmili, W., Wiedensohler, A., Wierprecht, W., Acker, K., Jaeschke, W., Kramberger, H., Svrcina, B., Bachmann, K., Collett, J. L., Galgon, D., Schwirn, K., Nowak, A., van Pinxteren, D., Plewka, A., Chemnitzer, R., Rud, C., Hofmann, D., Tilgner, A., Diehl, K., Heinold, B., Hinneburg, D., Knoth, O., Sehili, A. M., Simmel, M., Wurzler, S., Majdik, Z., Mauersberger, G., and Muller, F.: FEBUKO and MODMEP: Field measurements and modelling of aerosol and cloud multiphase processes, Atmos. Environ., 39, 4169-4183, doi:10.1016/j.atmosenv.2005.02.004, 2005.

Hinz, K. P. and Spengler, B.: Instrumentation, data evaluation and quantification in on-line aerosol mass spectrometry, J. Mass Spectrom., 42, 843-860, 2007.

Hinz, K. P., Greweling, M., Drews, F., and Spengler, B.: Data processing in on-line laser mass spectrometry of inorganic, organic, or biological airborne particles, J. Am. Soc. Mass Spectr., 10, 648-660, doi:10.1016/s1044-0305(99)00028-8, 1999.

Hinz, K. P., Erdmann, N., Gruning, C., and Spengler, B.: Comparative parallel characterization of particle populations with two mass spectrometric systems LAMPAS 2 and SPASS, Int. J. Mass Spectrom., 258, 151-166, doi:10.1016/j.ijms.2006.09.008, 2006.

Hitzenberger, R., Berner, A., Kromp, R., Kasper-Giebl, A., Limbeck, A., Tscherwenka, W., and Puxbaum, H.: Black carbon and other species at a high-elevation European site (Mount Sonnblick, $3106 \mathrm{~m}$, Austria): Concentrations and scavenging efficiencies, J. Geophys. Res.-Atmos., 105, 24637-24645, doi:10.1029/2000jd900349, 2000.

Jacobson, M. Z.: Strong radiative heating due to the mixing state of black carbon in atmospheric aerosols, Nature, 409, 695-697, doi:10.1038/35055518, 2001.

Jeong, C.-H., McGuire, M. L., Godri, K. J., Slowik, J. G., Rehbein, P. J. G., and Evans, G. J.: Quantification of aerosol chemical composition using continuous single particle measurements, Atmos. Chem. Phys., 11, 7027-7044, doi:10.5194/acp-11-70272011, 2011.

Kamphus, M., Ettner-Mahl, M., Klimach, T., Drewnick, F., Keller, L., Cziczo, D. J., Mertes, S., Borrmann, S., and Curtius, J.: Chemical composition of ambient aerosol, ice residues and cloud droplet residues in mixed-phase clouds: single particle analysis during the Cloud and Aerosol Characterization Experiment (CLACE 6), Atmos. Chem. Phys., 10, 8077-8095, doi:10.5194/acp-10-8077-2010, 2010.

Klimach, T.: Chemische Zusammensetzung der Aerosole: Design und Datenauswertung eines EinzelpartikelLaserablationsmassenspektrometers, Johannes GutenbergUniversität, Mainz, 2012.
Koehler, K. A., DeMott, P. J., Kreidenweis, S. M., Popovicheva, O. B., Petters, M. D., Carrico, C. M., Kireeva, E. D., Khokhlova, T. D., and Shonija, N. K.: Cloud condensation nuclei and ice nucleation activity of hydrophobic and hydrophilic soot particles, Phys. Chem. Chem. Phys., 11, 79067920, doi:10.1039/B905334b, 2009.

Korn, M. D. A., dos Santos, D. S. S., Welz, B., Vale, M. G. R., Teixeira, A. P., Lima, D. D., and Ferreira, S. L. C.: Atomic spectrometric methods for the determination of metals and metalloids in automotive fuels - A review, Talanta, 73, 1-11, doi:10.1016/j.talanta.2007.03.036, 2007.

Laj, P., Fuzzi, S., Facchini, M. C., Lind, J. A., Orsi, G., Preiss, M., Maser, R., Jaeschke, W., Seyffer, E., Helas, G., Acker, K., Wieprecht, W., Moller, D., Arends, B. G., Mols, J. J., Colvile, R. N., Gallagher, M. W., Beswick, K. M., Hargreaves, K. J., StoretonWest, R. L., and Sutton, M. A.: Cloud processing of soluble gases, Atmos. Environ., 31, 2589-2598, doi:10.1016/s13522310(97)00040-x, 1997a.

Laj, P., Fuzzi, S., Facchini, M. C., Orsi, G., Berner, A., Kruisz, C., Wobrock, W., Hallberg, A., Bower, K. N., Gallagher, M. W., Beswick, K. M., Colvile, R. N., Choularton, T. W., Nason, P., and Jones, B.: Experimental evidence for in-cloud production of aerosol sulphate, Atmos. Environ., 31, 2503-2514, doi:10.1016/S1352-2310(96)00217-8, 1997b.

Lanz, V. A., Prévôt, A. S. H., Alfarra, M. R., Weimer, S., Mohr, C., DeCarlo, P. F., Gianini, M. F. D., Hueglin, C., Schneider, J., Favez, O., D’Anna, B., George, C., and Baltensperger, U.: Characterization of aerosol chemical composition with aerosol mass spectrometry in Central Europe: an overview, Atmos. Chem. Phys., 10, 10453-10471, doi:10.5194/acp-10-10453-2010, 2010.

Limbeck, A. and Puxbaum, H.: Dependence of in-cloud scavenging of polar organic aerosol compounds on the water solubility, J. Geophys. Res.-Atmos., 105, 19857-19867, doi:10.1029/2000jd900123, 2000.

Liu, P., Ziemann, P. J., Kittelson, D. B., and McMurry, P. H.: Generating particle beams of controlled dimensions and divergence: 1. Theory of particle motion in aerodynamic lenses and nozzle expansions, Aerosol Sci. Technol., 22, 293-313, 1995a.

Liu, P., Ziemann, P. J., Kittelson, D. B., and McMurry, P. H.: Generating particle beams of controlled dimensions and divergence: 2. Experimental evaluation of particle motion in aerodynamic lenses and nozzle expansions, Aerosol Sci. Technol., 22, 314 324, 1995 b.

McFiggans, G., Artaxo, P., Baltensperger, U., Coe, H., Facchini, M. C., Feingold, G., Fuzzi, S., Gysel, M., Laaksonen, A., Lohmann, U., Mentel, T. F., Murphy, D. M., O’Dowd, C. D., Snider, J. R., and Weingartner, E.: The effect of physical and chemical aerosol properties on warm cloud droplet activation, Atmos. Chem. Phys., 6, 2593-2649, doi:10.5194/acp-6-2593-2006, 2006.

Mertes, S., Galgon, D., Schwirn, K., Nowak, A., Lehmann, K., Massling, A., Wiedensohler, A., and Wieprecht, W.: Evolution of particle concentration and size distribution observed upwind, inside and downwind hill cap clouds at connected flow conditions during FEBUKO, Atmos. Environ., 39, 4233-4245, doi:10.1016/j.atmosenv.2005.02.009, 2005a.

Mertes, S., Lehmann, K., Nowak, A., Massling, A., and Wiedensohler, A.: Link between aerosol hygroscopic growth and droplet activation observed for hill-capped clouds at connected flow 
conditions during FEBUKO, Atmos. Environ., 39, 4247-4256, doi:10.1016/j.atmosenv.2005.02.010, 2005b.

Middlebrook, A. M., Murphy, D. M., Lee, S.-H., Thomson, D. S., Prather, K. A., Wenzel, R. J., Liu, D.-Y., Phares, D. J., Rhoads, K. P., Wexler, A. S., Johnston, M. V., Jimenez, J. L., Jayne, J. T., Worsnop, D. R., Yourshaw, I., Seinfeld, J. H., and Flagan, R. C.: A comparison of particle mass spectrometers during the 1999 Atlanta Supersite Project, J. Geophys. Res.-Atmos., 108, 8424, doi:10.1029/2001JD000660, 2003.

Moffet, R. C. and Prather, K. A.: In-situ measurements of the mixing state and optical properties of soot with implications for radiative forcing estimates, Proc. Natl. Aca. Sci. USA, 106, 1187211877, doi:10.1073/pnas.0900040106, 2009.

Murphy, D. M., Middlebrook, A. M., and Warshawsky, M.: Cluster analysis of data from the Particle Analysis by Laser Mass Spectrometry (PALMS) instrument, Aerosol Sci. Technol., 37, 382-391, doi:10.1080/02786820390125241, 2003.

Ogren, J. A., Heintzenberg, J., and Charlson, R. J.: Insitu sampling of clouds with a droplet to aerosol converter, Geophys. Res. Lett., 12, 121-124, doi:10.1029/GL012i003p00121, 1985.

Petzold, A., Ogren, J. A., Fiebig, M., Laj, P., Li, S.-M., Baltensperger, U., Holzer-Popp, T., Kinne, S., Pappalardo, G., Sugimoto, N., Wehrli, C., Wiedensohler, A., and Zhang, X.-Y.: Recommendations for reporting "black carbon" measurements, Atmos. Chem. Phys., 13, 8365-8379, doi:10.5194/acp-13-83652013, 2013.

Posfai, M., Simonics, R., Li, J., Hobbs, P. V., and Buseck, P. R.: Individual aerosol particles from biomass burning in southern Africa: 1. Compositions and size distributions of carbonaceous particles, J. Geophys. Res.-Atmos., 108, 8483, doi:10.1029/2002jd002291, 2003.

Pratt, K. A. and Prather, K. A.: Aircraft measurements of vertical profiles of aerosol mixing states, J. Geophys. Res.-Atmos., 115, D11305, doi:10.1029/2009jd013150, 2010.

Pratt, K. A., Hatch, L. E., and Prather, K. A.: Seasonal Volatility Dependence of Ambient Particle Phase Amines, Environ. Sci. Technol., 43, 5276-5281, doi:10.1021/es803189n, 2009.

Pratt, K. A., Twohy, C. H., Murphy, S. M., Moffet, R. C., Heymsfield, A. J., Gaston, C. J., DeMott, P. J., Field, P. R., Henn, T. R., Rogers, D. C., Gilles, M. K., Seinfeld, J. H., and Prather, K. A.: Observation of playa salts as nuclei in orographic wave clouds, J. Geophys. Res.-Atmos., 115, D15301, doi:10.1029/2009jd013606, 2010.

Pratt, K. A., Murphy, S. M., Subramanian, R., DeMott, P. J., Kok, G. L., Campos, T., Rogers, D. C., Prenni, A. J., Heymsfield, A. J., Seinfeld, J. H., and Prather, K. A.: Flight-based chemical characterization of biomass burning aerosols within two prescribed burn smoke plumes, Atmos. Chem. Phys., 11, 1254912565, doi:10.5194/acp-11-12549-2011, 2011.

Rehbein, P. J. G., Jeong, C. H., McGuire, M. L., Yao, X. H., Corbin, J. C., and Evans, G. J.: Cloud and Fog Processing Enhanced Gasto-Particle Partitioning of Trimethylamine, Environ. Sci. Technol., 45, 4346-4352, doi:10.1021/es1042113, 2011.

Ross, K. E., Piketh, S. J., Bruintjes, R. T., Burger, R. P., Swap, R. J., and Annegarn, H. J.: Spatial and seasonal variations in CCN distribution and the aerosol-CCN relationship over southern Africa, J. Geophys. Res.-Atmos., 108, 8481, doi:10.1029/2002jd002384, 2003.
Roth, A.: Untersuchungen von Aerosolpartikeln und Wolkenresidualpartikeln mittels Einzelpartikel-Massenspektrometrie und optischen Methoden, $\mathrm{PhD}$ Thesis, University Mainz, 178 pp., available at: http://d-nb.info/1053202164/34 (last access: 8 January 2016), 2014 (in German).

Schade, G. W. and Crutzen, P. J.: Emission of alphaticamines from animal husbandry and their reactions - potential source of $\mathrm{N}_{2} \mathrm{O}$ and $\mathrm{HCN}$, J. Atmos. Chem., 22, 319-346, doi:10.1007/bf00696641, 1995.

Schneider, J., Weimer, S., Drewnick, F., Borrmann, S., Helas, G., Gwaze, P., Schmid, O., Andreae, M. O., and Kirchner, U.: Mass spectrometric analysis and aerodynamic properties of various types of combustion-related aerosol particles, Int. J. Mass Spectrom., 258, 37-49, 2006.

Schneider, J., Mertes, S., Van Pinxteren, D., Herrmann, H., and Borrmann, S.: In-situ mass spectrometric analysis of cloud residuals and interstitial aerosol composition on orographic clouds during HCCT-2010: Uptake of nitric acid in cloud droplets, Atmos. Chem. Phys. Discuss., in preparation, 2016.

Sedlak, D. L., Hoigne, J., David, M. M., Colvile, R. N., Seyffer, E., Acker, K., Wiepercht, W., Lind, J. A., and Fuzzi, S.: The cloudwater chemistry of iron and copper at Great Dun Fell, UK, Atmos. Environ., 31, 2515-2526, doi:10.1016/s13522310(96)00080-5, 1997.

Sellegri, K., Laj, P., Dupuy, R., Legrand, M., Preunkert, S., and Putaud, J. P.: Size-dependent scavenging efficiencies of multicomponent atmospheric aerosols in clouds, J. Geophys. Res.Atmos., 108, 4334, doi:10.1029/2002jd002749, 2003.

Sellegri, K., Umann, B., Hanke, M., and Arnold, F.: Deployment of a ground-based CIMS apparatus for the detection of organic gases in the boreal forest during the QUEST campaign, Atmos. Chem. Phys., 5, 357-372, doi:10.5194/acp-5-357-2005, 2005.

Shields, L. G., Suess, D. T., and Prather, K. A.: Determination of single particle mass spectral signatures from heavy-duty diesel vehicle emissions for PM2.5 source apportionment, Atmos. Environ., 41, 3841-3852, doi:10.1016/j.atmosenv.2007.01.025, 2007.

Silva, P. J. and Prather, K. A.: Interpretation of mass spectra from organic compounds in aerosol time-of-flight mass spectrometry, Anal. Chem., 72, 3553-3562, 2000.

Silva, P. J., Liu, D. Y., Noble, C. A., and Prather, K. A.: Size and chemical characterization of individual particles resulting from biomass burning of local Southern California species, Environ. Sci. Technol., 33, 3068-3076, doi:10.1021/es980544p, 1999.

Silva, P. J., Carlin, R. A., and Prather, K. A.: Single particle analysis of suspended soil dust from Southern California, Atmos. Environ., 34, 1811-1820, doi:10.1016/s1352-2310(99)00338-6, 2000.

Simoneit, B. R. T., Schauer, J. J., Nolte, C. G., Oros, D. R., Elias, V. O., Fraser, M. P., Rogge, W. F., and Cass, G. R.: Levoglucosan, a tracer for cellulose in biomass burning and atmospheric particles, Atmos. Environ., 33, 173-182, 1999.

Snyder, D. C., Schauer, J. J., Gross, D. S., and Turner, J. R.: Estimating the contribution of point sources to atmospheric metals using single-particle mass spectrometry, Atmos. Environ., 43, 40334042, doi:10.1016/j.atmosenv.2009.05.011, 2009.

Sodeman, D. A., Toner, S. M., and Prather, K. A.: Determination of single particle mass spectral signatures from light- 
duty vehicle emissions, Environ. Sci. Technol., 39, 4569-4580, doi:10.1021/es0489947, 2005.

Tilgner, A., Majdik, Z., Sehili, A. M., Simmel, M., Wolke, R., and Herrmann, H.: SPACCIM: Simulations of the multiphase chemistry occurring in the FEBUKO hill cap cloud experiments, Atmos. Environ., 39, 4389-4401, doi:10.1016/j.atmosenv.2005.02.028, 2005.

Tilgner, A., Schöne, L., Bräuer, P., van Pinxteren, D., Hoffmann, E., Spindler, G., Styler, S. A., Mertes, S., Birmili, W., Otto, R., Merkel, M., Weinhold, K., Wiedensohler, A., Deneke, H., Schödner, R., Wolke, R., Schneider, J., Haunold, W., Engel, A., Wéber, A., and Herrmann, H.: Comprehensive assessment of meteorological conditions and airflow connectivity during HCCT-2010, Atmos. Chem. Phys., 14, 9105-9128, doi:10.5194/acp-14-91052014, 2014.

Tolocka, M. P., Lake, D. A., Johnston, M. V., and Wexler, A. S.: Number concentrations of fine and ultrafine particles containing metals, Atmos. Environ., 38, 3263-3273, doi:10.1016/j.atmosenv.2004.03.010, 2004.

Trimborn, A., Hinz, K. P., and Spengler, B.: Online analysis of atmospheric particles with a transportable laser mass spectrometer during LACE 98, J. Geophys. Res., 107, LAC 13-11-LAC 13-10, 2002.

van Pinxteren, M., Fiedler, B., van Pinxteren, D., Iinuma, Y., Körtzinger, A., and Herrmann, H.: Chemical characterization of sub-micrometer aerosol particles in the tropical Atlantic Ocean: marine and biomass burning influences, J. Atmos. Chem., 72, 105-125, doi:10.1007/s10874-015-9307-3, 2015.

Vogt, R., Kirchner, U., Scheer, V., Hinz, K. P., Trimborn, A., and Spengler, B.: Identification of diesel exhaust particles at an Autobahn, urban and rural location using single-particle mass spectrometry, J. Aerosol. Sci., 34, 319-337, doi:10.1016/s00218502(02)00179-9, 2003.

Weimer, S.: Particle emission traffic and wood combustion and its impact on spatial distributions of submicron particulate matter, $\mathrm{PhD}$ thesis, Eidgenössische Technische Hochschule Zürich, 2008.
Wendisch, M. and Brenguier, J.-L.: Airborne Measurements for Environmental Research: Methods and Instruments, Wiley-VCH Verlag GmbH \& Co. KGaA, Weinheim, 2013.

Wobrock, W., Schell, D., Maser, R., Jaeschke, W., Georgii, H. W., Wieprecht, W., Arends, B. G., Mols, J. J., Kos, G. P. A., Fuzzi, S., Facchini, M. C., Orsi, G., Berner, A., Solly, I., Kruisz, C., Svenningsson, I. B., Wiedensohler, A., Hansson, H. C., Ogren, J. A., Noone, K. J., Hallberg, A., Pahl, S., Schneider, T., Winkler, P., Winiwarter, W., Colvile, R. N., Choularton, T. W., Flossmann, A. I., and Borrmann, S.: The Kleiner Feldberg Cloud Experiment 1990. An overview, J. Atmos. Chem., 19, 3-35, doi:10.1007/BF00696581, 1994.

Zelenyuk, A., Imre, D., Cai, Y., Mueller, K., Han, Y. P., and Imrich, P.: SpectraMiner, an interactive data mining and visualization software for single particle mass spectroscopy: A laboratory test case, Int. J. Mass Spectrom., 258, 58-73, doi:10.1016/j.ijms.2006.06.015, 2006.

Zelenyuk, A., Imre, D., Nam, E. J., Han, Y. P., and Mueller, K.: ClusterSculptor: Software for expert-steered classification of single particle mass spectra, Int. J. Mass Spectrom., 275, 1-10, doi:10.1016/j.ijms.2008.04.033, 2008.

Zelenyuk, A., Imre, D., Earle, M., Easter, R., Korolev, A., Leaitch, R., Liu, P., Macdonald, A. M., Ovchinnikov, M., and Strapp, W.: In Situ Characterization of Cloud Condensation Nuclei, Interstitial, and Background Particles Using the Single Particle Mass Spectrometer, SPLAT II, Anal. Chem., 82, 7943-7951, doi:10.1021/ac1013892, 2010.

Zhang, G. H., Bi, X. H., Chan, L. Y., Li, L., Wang, X. M., Feng, J. L., Sheng, G. Y., Fu, J. M., Li, M., and Zhou, Z.: Enhanced trimethylamine-containing particles during fog events detected by single particle aerosol mass spectrometry in urban Guangzhou, China, Atmos. Environ., 55, 121-126, doi:10.1016/j.atmosenv.2012.03.038, 2012.

Zhao, W. X., Hopke, P. K., and Prather, K. A.: Comparison of two cluster analysis methods using single particle mass spectra, Atmos. Environ., 42, 881-892, doi:10.1016/j.atmosenv.2007.10.024, 2008. 